\title{
Annelik Sanatı: Erken Cumhuriyet Dönemi Çocuk Dergilerinde Çocuğun Bedensel Kurgusu
}

\author{
SEVCAN BAŞBOĞA* \\ sevcanbasboga@gmail.com
}

Özet: 19 ve 20. Yüzyılda modern devlet yapılarının yükselmesine bağlı olarak ulus-devletin sınırlarının korunması, savunulması ve ekonomik kalkınma yoluyla güçlendirilmesi gibi amaçlar çerçevesinde insan faktörü ve üretken durumda olan neslin bedeni, sağlğ̆l, üretkenlik kapasitesi devletler için gittikçe önem kazanan bir alana dönüşmüştür. Zira modern iktidar yapıları, sahip oldukları biyo politika perspektifi ile nüfusu düzenleme sorumluluğu çerçevesinde toplumların gelecek ekonomik, sosyal, siyasal refahları, güvenlikleri açısından tüm bu alanın iktidar mekanizması tarafindan "düzenlenmesini” gerçekleștiriyorlardı. Bahsi geçen düzenleyici denetim mekanizmaları çerçevesinde odaklanılan konuların başında, sahip olunan nüfusun doğum, ölüm, yaşam süresi, doğurganlık oranları, genel sağllk düzeyi, salgin hastalıklar, hastalıkların sıklı̆̆l, hijyen ve beslenme gibi konular gelmekteydi.

Bu bağlamda Türkiye’de Cumhuriyet döneminde giderek güçlenen modern devletin oluşumuna paralel olarak nüfus ve nüfus ekseninde gelişen tüm süreçler devletin, temel müdahale alanlarının başında gelmiştir. Zira Cumhuriyetin kuruluş süreci öncesinde süren uzun savaş dönemlerinde, üretim ve savunma süreçlerinde aktif durumda olabilecek nüfusun önemli bir kısmının kaybedilmesi, kalanların ise güçsüz, sağlıksız, bakımsız ve salgın hastalıklarla boğuşuyor olması nüfus meselesinin, ülkenin geleceği açısından ne derece önemli bir mesele olduğunu göstermiştir.

Bu çalışmada temelde erken Cumhuriyet döneminde nüfus ve nüfusun arttırılması ve çocuklardan başlanarak toplumun sağliklılaştırılması eksenli çabaların, çocuk dergilerine nasıl yansıdığı? Çocuk bakımı konusundaki yetersizliklerin neler olduğu? Bu yönde annelere ve ebeveynlere dönemin çocuk dergileri aracıllğıyla ne gibi sağlık öğütleri, önerileri ve mesajlar verildiği? Gelecekte Cumhuriyetin yetişkin vatandaşları olacak olan çocukların gündelik hayatlarında hangi alıskanlıklara sahip olmalarının idealize edildiği sorularına yanıt aranacaktır. Bununla beraber tüm bu anlatı ekseninde ortaya çıkan ve erken Cumhuriyet dönemi nüfus perspektifinde idealize edilen çocuğun beden formunun nasıl bir beden olduğu ve bu beden yapısının, içerisinde yaşanılan siyasal ve sosyal konjonktür ile olan bağı, neden böyle bir bedene ihtiyaç duyulduğu sorunsallaştırilacaktır.

Bu çalışmada erken Cumhuriyet döneminde, devletin çocuk dergileri aracılığıyla nüfusu yeniden düzenlemesinin hangi gerekçelerle, hangi yöntem ve öneriler eşliğinde gerçekleştiğine

* Yıldız Teknik Üniversitesi, Sosyal Bilimler Enstitüsü, Doktora Öğrencisi.

Bu makale "Erken Cumhuriyet Dönemi Çocuk Dergilerinde Bedeni Ahlaki ve Terbiyevi Özellikleriyle İnşa Edilen Çocukluk” başlıklı doktora tez çalışmamdan yararlanılarak oluşturulmuştur. 
odaklanılmıştır. Bu çerçevede ülke nüfusunun artmasının önündeki en ciddi engellerin başında yaşanan çocuk ölümleri olduğu, bunu aşamanın yolu olarak da çocuk dergilerinde annelere ve ebeveynlere sağlıkl ve zinde nesilleri nasıl yetiştirmeleri gerektiği ile ilgili yöntem ve önerilere değinilmiştir. Böylece geleceğin sağlıklı beden yapısına sahip ve sağlık alışkanlıklarını yaşamın merkezine koyan yeni bir birey ve toplum anlayışının çocuk dergileri aracılığıyla nasıl inşa edilmeye çalışıldiğı ortaya konmuştur.

Anahtar Kelimeler: Modern Devlet, Çocuk Dergileri, Çocuk Bakımı, İdealize Beden.

\section{Giriş}

19 ve 20. Yüzyılda modern devlet yapılarının yükselmesine bağlı olarak ulus-devletin sınırlarının korunması, savunulması ve ekonomik kalkınma yoluyla güçlendirilmesi gibi amaçlar çerçevesinde insan faktörü, hele ki üretken durumda olan neslin bedeni, sağlığı, üretkenlik kapasitesi, devletler için gittikçe önem kazanan bir alana dönüşmüştür. Modernite ile beraber daha fazla önem kazanan insan bedeninin sağlı̆̆ ve üretkenlik kapasitesinin, temelde modern devletin bireylerinin, daha çocukluk yıllarından itibaren sağlıklı, güçlü ve dayanıklı olarak yetiştirilmesine bağlı olduğu anlaşılır. Foucault'un da belirttiği gibi modern iktidar yapıları, sahip oldukları biyo-politika perspektifi ile nüfusu düzenleme sorumluluğu çerçevesinde toplumların gelecek ekonomik, sosyal, siyasal refahları, güvenlikleri açısından tüm bu alanın iktidar mekanizması tarafından "düzenlenmesini” gerçekleştiriyorlardı. ${ }^{1}$

19 ve 20. yüzyıl başlarında da modern devlet yapılarının bahsi geçen düzenleyici denetim mekanizmaları çerçevesinde odaklandıkları temel konuların başında, sahip olunan nüfusun, doğum, ölüm, yaşam süresi, doğurganlık oranları, genel sağlık düzeyi, salgın hastalıklar, hastalıkların sıklığı, hijyen ve beslenme gibi konular gelmekteydi. Dolayısıyla modern devlet yapılarında, sahip olunan nüfus ve nüfusun niceliği, niteliği, özellikleri son derece önemli bir yerde duruyordu. Zira modern devlet için nüfus hem siyasal, hem de ekonomik gücü belirlemekteydi. ${ }^{2} \mathrm{Bu}$ bakış açısı modern iktidar yapıları açısından biyo-politiği oluşturan çıkış noktalarından birkaçını ve onun müdahale alanlarını gösterecektir ${ }^{3}$ ki konumuz açısından bakıldığında da Türkiye tarihinde, modern devletin oluşumuna paralel olarak nüfus ve nüfus ekseninde ortaya çıkan tüm süreçler, devletin temel müdahale alanlarının başında gelecektir. Bu çerçevede başta ülke nüfusunun arttırılması ve sağlıklı bir nüfusa sahip olunması çerçevesinde başlayan çözüm önerileri ile bu yöndeki düzenleme ve uygulamalar zamanla modern devletin ihtiyaç duyduğu sağlıklı bir nüfusa, bedene sahip bireyler/ vatandaşlar yetiştirme noktasında daha sistematik bir hale bürünmüştür. Bu bağlamda Cumhuriyet döneminde başta halk sağlığının korunması, ülke nüfusunun arttırılması, sağlıklı, nitelikli bir hale getirilmesi noktasından başlayan çözüm önerileri ile bu yöndeki girişim ve uygulamalar, Cumhuriyet yönetimince benimsenerek ve daha sistematik bir hale getirilerek, uygulanmaya çalışılmıştır. ${ }^{4}$

1 Michel Foucault, Cinselliğin Tarihi 1, çev. Hülya Tufan, 2. bs. İstanbul: Alfa Yayınları, 1993, s.143.

2 Foucault, Cinselliğin Tarihi 1, s. 31.

3 Michel Foucault, Toplumu Savunmak Gerekir, 6. bs. çev. Şahsuvar Aktaş İstanbul: Yapı Kredi Yayınları, 2013, s.250, 251.

4 Bu konuda ayrıntılı bilgi için bkz. Kemal Çelik, "Atatürk Dönemi C.H.P ve Hükümet Programlarında Sağlık" 
Cumhuriyet döneminde sağlık ve sosyal alanın düzenlenmesi çerçevesinde, bahsi geçen çalışmalar arasında üzerinde en fazla durulan konuların başında çocuk ölümlerinin azaltılması ve nüfusun arttırılması çabası bulunmaktaydı. Bu bağlamda ülke nüfusunun arttırılması, dolayısıyla doğumlar, çocuk bakımı ve hastalıklardan korunma, devletin odaklandığı ve üzerine politika geliştirdiği temel konuların başında yer almaktaydı.

Bu bağlamda ele alınan dönem içerisinde kitle iletişim araçlarının son derece yetersiz olduğu bir ortamda, ailelere, çocuklara, gençlere ulaşmanın en pratik yollarından biri de çocuk yayınları olmuştur. Bu tür yayınlar arasında çocuk dergileri önemli bir yer tutmaktaydı. Zira ele alınan dönem içerisinde yayımlanan çocuk dergilerinin ulaşmaya çalıştığı hedef kitle yalnızca çocuklarla sınırlı değil, aynı zamanda aile içerisinde çocuğun bakımı ve büyütülmesinden sorumlu olan ebeveynler ile okul öğretmenleri de ${ }^{5}$ bulunmaktaydı. Bu çalışmada örneklerine yer verilen dergilerde ${ }^{6}$ olduğu gibi dönemin çocuk dergisi olarak anılan yayınlar, dönemin bürokratları ya da görece aydın denebilecek kimseler tarafından çıkarılmıştır. ${ }^{7}$ Dergiler bu yönüyle Cumhuriyet yönetimi ile genellikle paralel denebilecek bir anlayış çerçevesinde, içerisinde yaşanılan siyasal ve sosyal konjonktürün gerçekliğinden hareket ederek, dönemin ihtiyaç duyduğu özelliklere sahip hastalıklardan arınmış, sağlıklı, gürbüz, güçlü ve zinde bedenleri olan çocukları inşa etme amacı taşımıştır. Bahsi geçen amaçlar çerçevesindeki söylem, anlatı ve sağlıklı yaşam önerileri tam da Cumhuriyet rejiminin sahip olmayı umduğu nüfusun, bedensel inşasını oluşturmaya dönüktü. Bu nedenle dönemin çocuk dergileri, aynı zamanda siyasal iktidarın nüfus, sağlık ve sosyal politikalarının önemli araçlarından biri olarak düşünülmüştür.

Bahsi geçen amaçlar çerçevesinde yayımlanan çocuk dergilerinde çocukların yaşatılması, sağlıklı, sıhhatli tutulması konusuna dair yazılar oldukça geniş yer tutmaktadır. $\mathrm{Bu}$ yanıla çocuk bakımı konusu fiilen ailelerin denetiminde bir alan olmakla bera-

Atatürk Dönemi Sağlık Tarihi Kongresi (1920-1938) Bildiriler, Editörler: Mustafa Mutluer, Eren Akçiçek, İzmir: Ege Üniversitesi Basımevi, 2009, s. 296-305. Mehmet Temel, Atatürk Döneminde Bulaşıcı ve Salgın Hastalıklarla Mücadele, Ankara: Nehir Yayınları, 2008, s.13, 14.

5 Erken Cumhuriyet döneminde yayımlanan çocuk dergileri, daha geniş bir okuyucu kitlesi ile buluşabilmek amacıyla genellikle altı aylık ya da bir yıllık dergi aboneliğini teşvik etmişlerdir. Bu çerçevede yalnızca bireysel abonelikler değil, çocukların toplu olarak bulundukları okul ve sınıf düzeyinde de abonelikler, hem okul yönetimlerine, hem de öğretmenlere önerilmiştir. Bu konuda ayrıntılı bilgi için bkz. Cüneyd Okay, Eski Harfli Çocuk Dergileri, İstanbul: Kitabevi, 1999, 18, 19.

$6 \mathrm{Bu}$ çalışmada ele alınan dergiler Erken Cumhuriyet döneminde yayımlanmış çocuk dergileri ile çocuklara dönük sağlık içerikli dergilerden oluşmaktadır. Bu dergilerin seçilme nedeni; ele alınan dönem içerisinde yayımlanmış olmalarının yanı sıra, çalışmanın içeriğine dair malzeme içermesidir. Çalışma içerisinde yer verilen çocuk ve sağlık dergileri şunlardır; Türk Çocuğu, Gürbüz Türk Çocuğu, Çocuk, Çocuk Haftası, Resimli Dünya, Asrın Çocuk, Yeni Yol, Ateş, Çocuk Sesi, Çocuk Duygusu, Doğan Kardeş, Cumhuriyet Çocuğu, Resimli Dünya, Çocuk Güneşi, Şen Çocuk, Resimli Mecmua, sağlık dergileri, Çocuk Bakımı, Çocuk Doktoru, Çocuk Salnamesi, Sihhi Sahifler, Hayat ve Sihhat.

7 Bu çalışmada da yer verildiği üzere Erken Cumhuriyet döneminde ilk sayısı Teşrin-i evvel 1926 yayımlanan Türk Çocuğu dergisi, (daha sonra Gürbüz Türk Çocuğu adıyla 1935’e kadar 108 sayı olarak yayımlanır. Dergi 1936-1947 yılları arasında Çocuk adıyla 427 sayı yayımlanır.) dönemin Kırklareli Mebusu, Sağlık Bakanı ve Himaye-i Etfal Cemiyeti Başkanı Doktor Fuad (Umay) tarafından yayımlanmıştır. Bunun gibi diğer çocuk dergileri de genellikle dönemin aydın, yazar ya da eğitimcileri tarafından yayımlanmıştır. Bu konuda ayrıntılı bilgi için bkz. Okay, Eski Harfli Çocuk Dergileri, 173-214. Veysi Akın, Bir Devrin Cemiyet Adamı: Doktor Fuad Umay, Ankara: Atatürk Araştırma Merkezi, 2000. 
ber devletin de bu konuda sorumlulukları olduğu vurgulanır. Bu sorumluluk çerçevesinde çocukların, yalnızca doğdukları aileye ait olmadığı aynı zamanda devlete ait oldukları fikri geliştirilerek, özellikle çocuk bakımı konusunda yapılan hataların önüne geçmek, yaşanacak olası çocuk ölümlerini engellemek ve çocuk bakımı konusunda başta anneler olmak üzere ebeveynleri, toplumu bilinçlendirmek amacıyla çeşitli uyarılarda bulunulmuştur. ${ }^{8}$

Çocuk bakımı ve sağlığı konusunda ailelere, ebeveynlere ve temelde topluma yol göstermek amacıyla çocuk dergilerinde yer alan çocuk bakımı ve sağlğ̆ını korumaya dönük yazılar genellikle dönemin hekimleri tarafından kaleme alınmıştır. Bahsi geçen yazıların konusu, çocuğun henüz dünyaya gelmeden önceki sürecinden itibaren başlamaktadır. Bu yazılarda temelde annelere, ebeveynlere çocuk bakımının neden bu derece önemsenmesi ve bu konuda neler yapılması gerektiği tüm detaylarıyla anlatılır. ${ }^{9} \mathrm{Bu}$ anlatılarda çocuk hıfzıssıhhasının, milletin müstakbel bir kuvveti olduğu, dolayısıyla bu konunun, ailevi bir konu olmaktan daha ziyade "milli" bir mesele olduğunun altı çizilir. ${ }^{10}$ Dolayısıyla da çocuk bakımı meselesi bu yanıyla milli devletin, "milli meselelerinden" biri olarak, yalnızca annelere, ebeveynlere, ailelere bırakılamayacak kadar ciddi ve önemli bir mesele olarak tanımlanır. ${ }^{11}$ Erken Cumhuriyet dönemi çocuk sağllğı konusu, devlet perspektifinde "milli bir mesele" olarak somutlaşırken, toplumu oluşturan her bir bireyin, kendisinin ve çocuklarının sağlığına gösterecekleri özen ile aslında toplumun, devletin sağlığına önemli bir katkı yapacakları belirtilir. Bu yanıyla "... umumun hayrı, ferdin hayrına bağlıdır." Denilerek toplumu oluşturan bireylerin kendi sağlıklarını korumak noktasındaki sorumlulukları aynı zamanda milli, toplumsal bir sorumluluk olarak kabul edilmiştir. ${ }^{12}$

\section{"Annelik Sanatı"13 : Çocuk Dergilerinde Annelere Çocuk Bakımı Öğütleri}

Erken Cumhuriyet döneminde, devleti sağlam bir şekilde ayakta tutacağına inanılan nüfusun, sağlam ve sağlıklı olması konusu, daha çocuğun dünyaya gelmeden önceki süreçte gözetilmesi gereken bir durumdur. Çocuk sağllğının, annenin gebelik süreci öncesinden itibaren başlayan bir durum olduğu, zira sağlıklı bir çocuk elde etmenin ilk koşulunun her bakımdan sağlıklı olan anne ve babaya sahip olmaktan geçtiği bilgisi önem kazanır. Diğer taraftan dergilerde, gebelik sürecinde bulunan bir annenin, bu süreçte yapması ve yapmaması gerekenler konusunda oldukça ayrıntılı anlatıların bulunduğu yazılarda, yazıyı kaleme alan hekim ya da yazar, tüm anlatı içerisinde konuya dair hiç bilgisi bulunmayan birine konuyu anlatır tarzda oldukça didaktik

8 Türk Çocuğu, "Bilmeyerek Yapılan Hayat Hırsızlıkları: Çocuklarımız Yalnız Bizim Değil Vatanındır da" s.3, (Kanun-1 evvel 1926):2. Zeki Mesut, “Çocuk Hakkında Günlük Arkadaşlarımız Ne Yazıyor.” Gürbüz Türk Çocuğu, 40/Kanun-1 sani (1930), s.24.

9 Türk Çocuğu, "Bilmeyerek Yapılan Hayat Hırsızlıkları: Çocuklarımız Yalnız Bizim Değil Vatanındır da", 3/ Kanun-1 evvel (1926), s.2.

10 Dr. Fatma Arif, "Çocuk Hıfzıssıhhası" Çocuk Haftası, (23 Nisan 1934/23 Nisan Özel Sayısı):75-83. Feridun Neşet Bey, "Sıhhi Sütunlar: Mukaddime" Yeni Yol, 28/15 Mart (1924), s. 2.

11 Zeki Mesut, "Çocuk Hakkında Günlük Arkadaşlarımız Ne Yazıyor: Çocuk Sıhhati” Gürbüz Türk Çocuğu, 40/ Kanun-i sani (1930), s.24.

12 Çocuk Salnamesi, "Çocuklarınıza İyi Bakınız" (1927): 32. Özmen (İstanbul saylavı), "Çocuk” Gürbüz Türk Çocuğu, 102/Haziran (1935), s.9-11.

13 “Annelik Sanatı: Bu Kutsi Sanatı Tamim Etme Sanatıdır” Türk Çocuğu, 14/Teşrin-i Sani (1927), s.21. 
denebilecek bir üslup benimsemiştir. Dolayısıyla çocuk bakımı ve beslenmesi konusunu ele alan bu yazılarda, bir taraftan toplumda geçmişten gelen yanlış bilgilerin geçersizliğine vurgu yapılırken, diğer taraftan da bu sürecin en doğru haliyle nasıl olması gerektiği anlatılmaya çalışılmıştır.

Dergilerde, Türk kadınlarının çocuk bakımı konusunda yeterince bilgi sahibi olmadıkları ve özellikle fenni-bilimsel bilgiden yoksun ve "cahil” olduklarının altı çizilirken, ${ }^{14}$ bu konudaki yetersizliğin kaynağ 1 da annelerin eğitimsizlikleri, çocuk yetiştirime konusunda "fenni bir usulü" bilmedikleri, takip etmedikleri gerçeğine işaret edilir. ${ }^{15}$ Zira çocuk bakımı konusunda, anne adaylarının, ebeveynlerin bildiklerinin kaynağında, "ya validesinden gördükleri, komşusundan duydukları ya da hocasından öğrendiği derme çatma, kulaktan dolma bilgiler" bulunduğu, ${ }^{16}$ bilinen bu bilgilerin de "hurafelere ve bu hurafelerden üretilen koca karı ilaçlarına" dayandığı konu edilir. Bu yanıyla temelde toplumda çocuk bakımı konusunda bilimsel yöntemlere dayalı bir bilgi birikiminin olmadığı, bu nedenle de çocuk bakımı konusunda genel olarak Türk kadınlarının zorlandıkları ve genellikle çocuklarının, ya sürekli hasta olduğu ya da bir yaşını doldurmadan hayatlarını yitirdikleri vurgulanır. ${ }^{17}$ Bununla beraber bu konuda yapılması gereken öncelikli şeyin, özellikle annelerin, eğitim düzeylerinin yükseltilmesi gerektiğidir. Ebeveynlerin, çocukların bakımı, temizlik, hijyen alışkanlıkları, hastalıklardan korunması konularında alacakları eğitimler ve yapılacak bilgilendirmeler ile bu konudaki sorunların zamanla aşılmasının mümkün olacağ 1 kabul edilir. ${ }^{18}$

Çocuk Dergilerinde, ele alınan dönem içerisinde, yaygın olan çocuk ölüm oranlarını azaltma, sağlıklı çocuk yetiştirme usulleri, hastalıklardan korunma, salgın hastalıklarla mücadele çerçevesinde genel olarak yirmili ve otuzlu yıllarda oldukça yoğun bir bilgilendirme ve tartışma yürütüldüğü görülür. Bu bağlamda Avrupa'da, çocuk bakımı konusunda en başarılı olan ülkeler tespit edilmeye çalışılır. Bu konuda temel kriter olarak çocuk ölüm oranları esas alınır. Genel olarak Avrupa ülkelerinin, bu konuda başarılı bulunduğu, ancak ölüm oranlarının düşüklüğü ve çocuk yetiştirme usullerindeki başarı açısından Almanya ve Norveç’in ön planda olduğu görülür. ${ }^{19}$

Çocuk bakımı ve yetiştirilmesi konusunda ön plana çıkan ve bu konuda model alınması gereken ülkenin ağırlıklı olarak Almanya olması gerektiği belirtilir. ${ }^{20}$ Ancak çocuk hastalıkları mütehassısı olan Dr. Ali Şükrü Bey, Avrupa’da uygulanmakta olan

14 Dr. İhsan Hilmi Bey, “Doktor İhsan Hilmi Bey Diyor ki: Çocuk Bakımında En İyi En Muvafık Usul” Çocuk Haftas1, c.2/23 Nisan (1930), s.72, 24.

15 Dr. Rıza Tahir Bey, “Çocuk Bakımına Ait Öğütler”, Türk Çocuğu, 14/Teşrin-i Sani (1927), s. 18,19. Özmen (İstanbul saylav), "Çocuk” 9-11.

16 Dr. Rıza Tahir Bey, “Doğumundan İtibaren Sütten Kesilinceye Kadar Çocuk Bakımı” Türk Çocuğu, 14/Teşrin-i sani (1927), s. 18, 19.

17 Çocuk Salnamesi, “Tabibi Beklerken” (1927) 26-27.

18 Dr. Rıza Tahir Bey, “Doğumundan İtibaren”, 18, 19. Dr. M.Ç, “Çocuk Nasıl Büyütülür” Sihhi Sahifeler, 5/15 Mayıs (1924), s.80.

19 Dr. Niyazi Ali Bey, “Çocuk Nasihat Yuvaları: Doktor Niyazi Ali Bey’in Fikri” Çocuk Haftası, c.2/23 Nisan (1930), s. 77, 78. Bu yazıda Norveç’te çocuk ölüm oranları binde 79 olarak Avrupa ülkeleri içerisindeki en düşük oran olarak gösterilir.

20 Dr. Niyazi Ali Bey, “Çocuk Nasihat Yuvaları", 77, 78. 
bu usullerin, “... memleketimizin bazı mücerrep ve faydalı olan usulleri ile birleştirerek, bu suretle çocuk büyütülmesi konusunda bir hattıhareket çizilmesi” gerektiği, bununla beraber çocuk bakımı konusunda model alınması gereken Almanların, bu konuda önemli bir ilerleme kaydederek, hem konuyu en teferruatlı şekilde inceledikleri, hem de konuya dair en pratik ve kolay yöntemi buldukları belirtilir. Almanların, özellikle çocuk beslenmesi, çocuk terbiyesi ve çocuk eğitimi konularını inceleyip, bu yönde basit, pratik toplum için en faydalı yöntemleri geliştirmiş oldukları, zira Almanya’da annelerin, çocuklarını hep bir düzen ve sistem içerisinde yetiştirdikleri vurgulanır. Alman çocuk yetiştirme usulünde, çocukların belli saatlerde uyuyup belli saatlerde uyandıkları, belli saatlerde beslenip, temizlik alışkanlıklarını da bu sistem içerisinde gerçekleştirdikleri ortaya konur. Dolayısıyla çocuk bakımı meselesinin, Almanya’da anneler ve ebeveynler tarafından belirlenmiş bir sistem dâhilinde yürütüldüğü böylece annelerin, çocukların esiri olmadıkları, bununla beraber çocukların da anneye büyüme sürecinde yük olmadıkları bir döngü tasvir edilir. ${ }^{21}$

Çocuk bakımı konusunda çocuk dergilerine bakıldığında, çocuk bakımı ile ilgili önem ve hassasiyetin, annenin henüz gebelik aşmasında iken başlaması gerektiği yönündedir. Zira annenin sıhhati, çocuğun sıhhatli olması yönünde de büyük önem taşımaktadır. ${ }^{22}$ Annenin bu süreci dengeli ve sağlıklı bir şekilde geçirebilmesi için hem beslenme ve jimnastik faaliyetlerine, hem de hastalıklardan korunmaya özen göstermesi gerektiği vurgulanır. ${ }^{23} \mathrm{Bu}$ dönemin bahsi geçen gerekleri yerine getirildiği takdirde çocuğun gelişiminin de normal ve sağlıklı bir şekilde gerçekleşeceği belirtilirken, dergilerde bu sürece dair yapılması gerekenler konusunda Almanya ve Avusturya örneklerinden hareket edilir. ${ }^{24}$ Bahsi geçen bakım sürecindeki hataların, hem annenin, hem de çocuğun çeşitli hastalıklara yakalanmasına zemin hazırlayacağı, bu konudaki daha ciddi hataların ise çocuğu ölüme götürebileceği riski taşıdığı belirtilir. $^{25}$

Ancak yukarıda bahsi geçen sürecin, normal olmayan bir şekilde cereyan etmesi halinde bebeğin vaktinden önce doğmasının da mümkün olacağı, bu şekilde doğan çocuklara nasıl bir bakım yapılması gerektiği de yine Almanya'da, Berlin'deki bir hastanenin, erken doğan çocuklar için ayrılmış bölümünden hareket edilerek anlatılır. ${ }^{26}$ Bununla beraber Dr. Ali Rifat, yeni doğan bir çocuğun sağlıklı olup-olmadığını onun fiziksel görüntüsüne bakarak anlamanın mümkün olduğunu belirtir. Zira buna göre, sağlıklı bir çocuğun "rengi taze, cildi parlak, elleri sıkı, iştah ve uykusu iyi, hazmı mükemmel, vezni ise muntazamdır."27

21 Dr. Ali Şükrü Bey, "Çocuk Bakımı İlmi: Dr. Ali Şükrü Bey’in Mütalaası” Çocuk Haftası, c.2, /23 Nisan (1930), s. 75,76 .

22 Çocuk Salnamesi, "Annelerin Sıhhati Umumun Sihhati", ( 1927), s. 129, 130.

23 Dr. Ali Şükrü Bey, Yeni Doğmuş Çocukların Bazı Hususiyetleri, Gürbüz Türk Çocuğu, 9/1 Haziran (1927), s. 1-7. Gürbüz Türk Çocuğu, "Baş Başa: Doğum ve Çocuk Himayesi", 49, /Teşrin-i evvel (1930), s. 3. Çocuk Salnamesi, "Sağlığınızı Muhafaza Etmek İsterimsiniz?” (1927): 87-88.

24 Gürbüz Türk Çocuğu, "Annelere Çocuk Bakımı Öğütleri”, 58/Temmuz (1931), s. 8.

25 Dr. Ali Şükrü Bey, "Sağlam Çocukların Muhtelif Aylarında Bulunması Lazım Olan Evsaf", Gürbüz Türk Çocuğu, 8/1 Mayıs (1927), s. 5-10 Bu konuda ayrıca bkz. "Uyanıklar Mektebi Çocuklarının Sıhhat Cetveli” Türk Çocuğu, 4/Kanun-1 sani (1927), s. 6, 7.

26 Gürbüz Türk Çocuğu, "Vaktinden Önce Doğan Çocuklar", 66/Mart (1932), s. 7, 8.

27 Dr. Ali Rıfat, "Çocuk Memleketin Varlığı, Ümidi, İstikbali Her şeydir" Gürbüz Türk Çocuğu, 81/Temmuz 
Çocuk dergilerinde yazı yazan dönemin çocuk hekimleri, annelere, çocuğun bakımı konusunda sıklıkla, "Çocuklarınızın sıhhati konusunda gerekli fenni ve sıhhi bilgiye sahip misiniz? Bunlar yalnız nazariye halinde midir? Yoksa tatbikat halinde midir? Çocuğunuzun sıhhatindeki noksanlıkları biliyor ve bunları takip ve tedavi ettirmeye çalışıyor musunuz?" şeklindeki sorularla uyarılarda bulunarak, bu konuda bir farkındalık yaratmak istemişlerdir. ${ }^{28}$

Çocuk yetiştirmenin, büyütmenin dahası sağlıklı ve zinde bedenleri olan çocuklara sahip olmanın pek de kolay olmadığı, zira bu konuda mesafe kat etmenin zorluğu sıkça vurgulanmıştır. Bu zorlu konuda annelere yardımcı olmak üzere çocuk dergilerinde, sıklıkla "Annelere, çocuklar için sıhhi öğütler” başlıklı yazılarla bu konudaki zorluğu aşmak, anne ve çocuk sağlığı bakımı konusunda en sağlıklı ve bilimsel bilginin, gündelik bir dille anlatılmasına çalışılmıştır. ${ }^{29}$ Çocuk dergilerinde çocuktan, çocuk bakımından, çocuğun yaşatılması ve sağlıklı hale getirilmesinden sorumlu asıl kişinin anne olduğu, bu zor, meşakkatli görevin verildiği annelerin hem bir canlıya-bebeğe hayat verdiği hem de ona gerekli bakımları sağlayarak aslında "kutsal" bir görevi üstlendiği ortaya konur. Dergilerde sıklıkla üzerinde durulan ve "annelik" ekseninde kutsallaştırılan görev ve sorumluluklar, dönemin anne olan kadınlarının en önemli işi, görevi, hatta doğuştan getirilen bir sorumluluğu olarak vurgulanmıştır. Bu yanıyla dönemin yaygın söyleminde, annelik, çocuk bakımı ve kutsallık arasında bağ kurularak annenin, çocuğuna iyi bakması ile kutsal bir görevi icra etmesi özdeşleştirilmiştir. ${ }^{30}$

\section{“Gürbüz Çocuk Nasıl Meydana Gelir”31: Çocuğun Temizlik-Hijyen, Uyku, Giyinme Alıșkanlıkları}

Gebelik sürecini ve doğum aşamasını takip eden dönemde, yani yeni doğmuş olan çocuklara nasıl bir bakım yapılması ve henüz doğmuş olan çocuğun "hususiyetlerinin" neler olduğu belirtilirken, yeni doğan çocuğun evde geçireceği ilk zamanlarda yapılması gerekenler adım adım ve tüm ayrıntısıyla ebeveyne anlatılır. ${ }^{32} \mathrm{Bu}$ anlatılarin hedefinde genellikle anne olsa da babaların da ebeveyn olarak sorumluluk almaları gerektiği zaman zaman hatırlanacaktır. ${ }^{33}$

(1933), s. 13-18.

28 Fatma Reşid, “İçtimai ve Sıhhi Dertlerimizden Biri: Doğduktan Sonra Ölen Çocuklar Değil Doğmadan Ölen Çocuklar Meselesi” Türk Çocuğu, 16/Kanun-1 sani (1928), s. 1-3. Dr. Ali Şükrü Bey, "Sağlam Çocukların”, 5-10. Bu konuda ayrıca bkz. "Uyanıklar Mektebi Çocuklarının Sıhhat Cetveli” Türk Çocuğu, 4/Kanunun-1 sani (1927), s. $5-10$.

29 “Annelerle Çocuklara Sıhhi Öğütler” Türk Çocuğu, 4/Kanunun-1 sanı (1927), s. 33, 34. Türk Çocuğu “Ebeveynin Günahları", 4/Kanunun-1 sani (1927), s. 13-15. Türk Çocuğu, "Çocuğunuza Rehber Olunuz”, 4/Kanun-1 sanı (1927), s. 1. Türk Çocuğu, "Ebeveynin Vazifeleri ve Ebeveynlik”, 2/Teşrin-i sani (1926), s. 1.

30 “Annelik Sanatı: Bu Kutsi Sanatı Tamim Etme Sanatıdır” Türk Çocuğu, 14/Teşrin-i Sanı (1927), s. 21.

31 Tarhan Taraç, “Gürbüz Çocuk Nasıl Meydana Gelir” Türk Çocuğu, 2/Teşrin-i sani (1926), s. 8-9.

32 Ali Şükrü Bey, “Doğacak Çocuklar İçin Sıhhi Ne Gibi Hazırlık Yapılmalıdır?” Gürbüz Türk Çocuğu,5/Şubat (1927), s. 4-7. Aynı yönde bilgi için bkz. "Çocuk Bakımına Ait Öğütler”, Türk Çocuğu,16/Kanun-1 sani (1928), s. 14, 15. Selim Sırrı, “Genç Annelerle Hasbıhal: Yeni Doğan Yavrular İçin Umumi Tavsiyeler” Gürbüz Türk Çocuğu, 28/Kanun-1 sani (1929), s. 6. Dr. Fahriye, "Çocuğun Ruhi Oluşu” Gürbüz Türk Çocuğu,103/Temmuz (1935), s. 14-17.

33 Prof. Dr. İhsan Hilmi, "Yeni Doğmuş Çocuk Karşısında Babanın Vazifesi” Gürbüz Türk Çocuğu, 81/Temmuz (1933), s. 19-21 Çocuk Doktoru, “Süt Çocuğu Bakımı” 1/Nisan (1946), s. 18, 19. 
Çocuk bakımı anlatısı dâhilinde; yeni doğmuş olan bir çocuğun evdeki ilk zamanlarında yapılması gerekenler ortaya konurken, sıhhi çocuk yuvası nasıl olmalıdır? Sorusu ekseninde çocuğun evdeki odasının konumu, yatağı, odada bulunması gereken eşyalar, odanın temizliği, havalandırılması gibi hususlar oldukça ayrıntılı bir şekilde belirtilir. ${ }^{34}$ Ancak anladığımız kadarıyla bu anlatılarda resmedilen çocuk yuvası dönemin koşulları düşünülecek olursa genellikle kentli, orta sınıf ailelerin sahip olabileceği olanaklar çerçevesinde organize edilebilecek niteliktedir. Toplumun \% 80'ninin köylü olduğu erken Cumhuriyet toplum yapısı içerisinde, bahsedilen çocuk bakımı ve yetiştirilmesi olanakları, sıradan bir aile için tam olarak yerine getirilmesi kolay olmayacak koşulları içermektedir. Ancak bahsi geçen dergilerde sağlıklı bir çocuğun büyütülmesi ve bakımı çerçevesinde idealize edilen tablo, kentli orta sınıf bir ailenin olanakları esas alınarak resmedilmiştir.

Yeni doğmuş çocuklar için üzerinde en fazla durulan konulardan biri de çocukların temizlik ve hijyeni meselesidir. Çocuk dergilerinde, özellikle yeni doğan çocukların, steril bir ortamda olması ve annesi dışındaki insanların çocukla temas etmemesi gerektiği konusu oldukça önemsenmiştir. Zira dönem içerisinde çocuk ölümleri açısından da "felaket" olarak adlandırılacak olan salgın hastalıkların bulaşmasının temel sebeplerinden biri ve en yaygın olanı da hastalıklı kimselerin çocukla temas etmesidir. $^{35}$

Yeni doğan çocukların temizliği konusunda dikkat çekilen diğer bir konu, çocuğun göbek bağının temizliği ve pansumanıdır. Zira yeni doğan çocuklarda bu bölgenin temizlik ve hijyenine dikkat edilmediği takdirde çocuğun mikrop kapması ve rahatsızlanmasının kaçınılmaz olacağı, bunun da çeşitli hastalıklara sebep olacağıdır. ${ }^{36}$ Bunun dışında çocuğun gündelik temizliğinde banyonun önemli bir yeri olduğu ve bebeklerin haftada birkaç kez 1lık su ile yıkanmaları gerektiği, ilerleyen süreçte ise çocuğun soğuk su ile yıkanmasının ${ }^{37}$ vücudunun direnç kazanmasında etkili olacağı üzerinde durulur. ${ }^{38}$ Bununla beraber güneş banyosunun da çocuğun, başta kemik ve cilt gelişimi olmak üzere vücudu üzerinde olumlu etkileri olduğ ${ }^{39}$ ayrıca, güneş banyosu ve genel olarak güneş kürlerinin, çocuğun hastalıklardan korunmasında de-

$34 \mathrm{Bu}$ anlatılarda henüz doğmuş olan çocukların odasının ısı derecesi, havalandırılması, güneşe olan konumu, çocuğun yatağının duruşu ve nasıl olması gerektiği, çocuğun odasında bulundurulması gereken eşyalar, çocuk odasının temizliği gibi konular tüm ayrıntısıyla ortaya konmuştur. Ali şükrü Bey, "Doğacak Çocuklar İçin Sıhhi Ne Gibi Hazırlık Yapılmalıdır?” Gürbüz Türk Çocuğu, 5/Şubat (1927), s. 4-7. Aynı yönde bilgi için bkz. "Çocuk Bakımına Ait Öğütler”, Türk Çocuğu,16/Kanun-1 sani (1928), s. 14, 15. Selim Sırrı, "Genç Annelerle Hasbıhal: Yeni Doğan Yavrular İçin Umumi Tavsiyeler” Gürbüz Türk Çocuğu, 28/Kanun-1 sani (1929), s. 6.

35 Dr. Asım İyen, "Hekim Öğütleri: Çocuk Bakımı”, Gürbüz Türk Çocuğu, 95/İkinci teşrin, (1934), s. 16. "1001 Soru ve Cevap: Sabun Niçin Temizler, Niçin Yıkar” Şen Çocuk, 5/5 Aralık (1945), s. 2.

36 Dr. Ali Rifat, "Çocuk Sihhati ve Bunun Ehemmiyeti” Gürbüz Türk Çocuğu, 81/Temmuz (1933), s. 13-18.

37 Dr. Ali Şükrü Bey, "Banyonun Faideleri ve Sıhhi Banyo Usulleri” Türk Çocuğu, 7/Nisan (1927), s. 15-18. Rıza Tahir Bey, "Yeni Doğan Çocukların Temizliğine Dikkat Etmek Ana ve Babaların En Büyük Vazifesidir." Gürbüz Türk Çocuğu, 29/Şubat (1929), s. 12, 13. Dr. Fahrettin Kerim, "Çocuk Banyosu” Sihhi Sahifeler, 8/15 Ağustos (1923), s. 125. Hasan Ali Ediz, “1001 Soru ve Cevap: İnsanlar Ne Zamandan Beridir Yıkanıyorlar?” Şen Çocuk, 4/28 Kasım (1945), s. 9. Emin Şükrü, “Çocuk Yetiştirmek Büyütmek İnce Bir Sanattır” Türk Çocuğu, 11/Ağustos (1927), s. 12-15.

38 Dr. Rıza Tahir Bey, “Doğumundan İtibaren” 18, 19. Dr. İhsan Hilmi Bey, "Çocuk Bakımında En İyi Usul”, Çocuk Haftası, c.2/23 Nisan (1930), s. 72-74.

39 Gürbüz Türk Çocuğu, “Çocuklara Güneş Banyosu Yaptırınız”, 34/Temmuz (1929), s. 5, 6. 
niz havası, iklimi ve deniz suyunun da oldukça yararlı olduğudur. ${ }^{40}$ Ancak güneşte kalma süresinin ve güneşin konumunun, güneş banyosunda dikkat edilmesi gereken en önemli husus olduğu, çocuğun ten rengi ve yaşına göre güneşte kalma süresinin ayarlanması gerektiği belirtilir. ${ }^{41}$ Çocuklarda temizlik alışkanlıklarının oluşumunda ailenin çok önemli bir rolü olduğu, zira çocukların ilk temizlik ve yaşam alışkanlıklarını da aile içerisinde kazandıkları belirtilir. ${ }^{42} \mathrm{Bu}$ yanıyla ailelerin, bebeklik sürecinden çocukluğa evirilen dönemde çocuklara gündelik yaşam içerisinde uymaları gereken temizlik ve hijyen alışkanlıklarını kazandırmaları, çocukların mikroplardan ve salgın hastalıklardan korunmaları açısından oldukça önemli olduğu üzerinde durulur. ${ }^{43}$ Bahsi geçen ve üzerinde sıklıkla durulan alışkanlıklardan biride çocukların genel sağlı̆̆ı için her gün dişlerin, yemeklerden sonra firçalanması gerektiğidir. Zira ele alınan dönem içerisinde çocukların ve yetişkinlerin en sık yakalandıkları salgın hastalıklardan olan veremin başlaması ve bedende gelişiminde genel olarak ağız ve diş hastalıkları da etkili olmuştur. Bu nedenle ağızda oluşacak mikrobik ortamın pek çok salgın hastalığa zemin hazırlayacağı bunu önlemenin tek yolunun ise ağız ve diş bakımı, temizliğinin her gün düzenli olarak yapılması gereğidir. ${ }^{44}$

Çocuk dergilerinde, çocukların daha çocukluk yıllarından itibaren sahip olmaları gereken sağlıklı yaşama kuralları ve temizlik alışkanlıkları sıklıkla hatırlatılmıştır. ${ }^{45}$ Böylece daha çocukluk ve okul yıllarında kazanılan temizlik alışkanlıklarının gelecek yaşamlarında da gündelik yaşam alışkanlıklarının temellerini oluşturacağı belirtilir. Böylece Cumhuriyetin idealize ettiği ve modern toplumların gündelik yaşam

40 Dr. G. Barrund, “Çocuklarda Güneş Banyosu ve Kürlerin Tekniği” Gürbüz Türk Çocuğu, 66/Mart (1932), s. 12, 13. Lokman Hekim, "Hekim Ögütleri: Hava Banyosu” Çocuk Duygusu, s. 27 (20 Eylül 1937): 13.

41 Lokman Hekim, “Güneşte Derisini Yakanlara Üzülüyorum” Çocuk Duygusu, 48/26 Ağustos (1938), s. 1. Ateş, “Güneş Büyük Düşman” 28/7 Haziran (1938), s. 6. Yeni Yol, "Güneş Nasıl çarpar” 68/19 Mart (1925), s. 709.

42 Türk Çocuğu, "Temiz Aile Manzumeleri”, 1/Teşrin-i evvel, (1926), s. 4.

43 Çocuk Sesi, "Mehlika Ablanın Nasihatleri” 69/7 Mayıs (1931), s. 13. Cumhuriyet Çocuğu, "Canını Seven Her İnsanın Bilmesi ve Uyması Gereken Kurallar" 25/20 Nisan (1939), s. 419. Sezai Bertan, "Temizlik ve İntizam” Çocuk Güneşi, 6/28 Ekim (1950), s. 5. Yeni Yol, "Hekim Aksungur Bey’in Öğütleri: Temizlik” 66/5 Mart (1925), s. 689,699 .

44 Gürbüz Türk Çocuğu, "Diş Fırçası Ailesinin Hikâyesi” 20/Mayıs (1928), s. 16, 17. Dr. Şadiye Muhiddin, "Diş Bakımı ve Sıhhatimiz" Gürbüz Türk Çocuğu, 74/Birinci Kanun (1932), s. 15-17. Dr. Şadiye Muhiddin, "Dişleri Koruma Usulleri” Gürbüz Türk Çocuğu, 87/Şubat (1934), s. 30, 32.

45 Bu kurallar şöyle sıralanmıştır;

"Her vakit temiz hava teneffüs ediniz.

Oynarken ve çalışırken temiz hava alınız.

Mümkün olduğu kadar temiz havada kalınız.

Uyurken pencereleri açık bırakınız.

Ağzınızla değil burnunuzla nefes alınız.

Haftada en az bir kez yıkanınız.

Elbiselerinizi temiz tutunuz.

Mektepte rahlede dik durunuz.

Evinizi ve mektebinizi kirletmeyiniz.

Yatmadan evvel dişlerinizi yıkayınız.

Yerlere tükürmeyiniz.

Ağzınıza olur olmaz şey koymayınız.

Yemeğe giderken ve abdesthaneden çıkarken ellerinizi yıkayınız." Türk Çocuğu, "Bu Kaideleri Ezberleyinceye Kadar Okuyunuz", 23 (Ağustos, 1928): 21. 
alışkanlıklarını oluşturan, temizlik hijyen kurallarını bilen çocuklar gelecekte sağlıklı ve salgın hastalıklardan arınmış bir toplumun temellerini atmış olacaklardı. ${ }^{46}$

Çocukların bakımı sürecinde, üzerinde durulan konulardan biri de çocukların gelişimi açısından oldukça önemli bulunan, çocukların ve bulundukları ortamın uygun aralıklarla havalandırılması meselesidir. Bu bağlamda evlerin inşası aşamasında dahi dikkat edilecek konuların başında evin havalandırılmasını kolaylıkla sağlayacak şekilde inşa edilmesi telkin edilir. ${ }^{47} \mathrm{Bu}$ yanıyla çocukların ilk doğdukları günden itibaren açık ve temiz havaya ihtiyacı olduğu, zira açık ve temiz havanın, bütün vücut fonksiyonları için olmazsa olmaz bir önemi bulunduğu gerçeğidir. ${ }^{48}$ Hasta, zayıf ve çelimsiz çocuklara dönük tedavilerin de açık havada yapılması önerilirken, ${ }^{49}$ buna karşın kapalı ortamlarda yetişen çocuklarda ilk fark edilen şeyin, çocuğun yeterince büyüyüp gelişmediği ve uzuvlarının yaşıtlarının gerisinde bir gelişme ortaya koyduğudur. Burada açık havadan kast edilen şeylerden birinin de, çocukların güneş alması ve başta kemik gelişimi olmak üzere beden gelişimini sağlıklı bir şekilde sağlamasıdır. ${ }^{50}$ Zira havasız ortamlarda güneş görmeden yetişen çocukların, sıklıkla hasta olduğu, ciğerleri ve bedeninin de yeterince güçlü olmadığ bundan dolayı vereme ve diğer hastalıklara da yakalanma olasılığının daha fazla olduğu vurgulanır. ${ }^{51}$ Havasız kalan çocukların aynı zamanda "güzel” çocuklar olmadığı, zira dergilerin idealize ettiği "gürbüz çocuk güzelliğinin” bu çocuklarda olmadığı, kısacası idealize edilen sağlıklı, güçlü, gürbüz, zinde Türk çocuğunu elde etmenin yollarından birinin de mutlaka çocukların açık havada ve güneş görerek büyümeleridir. ${ }^{52}$

Oyun yaşına gelmiş olan çocukların ise özellikle iyi havalarda, yaz aylarında sıklıkla açık havada olmaları ve oynamaları önerilir. Açık havanın insanı zinde yaptığı, ataletten uzaklaştırdığı, müşahede ve muhakeme kudretini arttırdığı, çocuğu her daim cevval kıldı̆̆ından bahsedilir. ${ }^{53}$

Çocukların bakımı, büyüme ve gelişme süreçlerindeki en önemli faktörlerden biri de zamanında ve yeterli düzeyde uyumalarıdır. ${ }^{54}$ İlk bir yaş içerisinde bebeklerin günde

46 Ş.Orhan, “Temizlik ve İntizam” Çocuk, 131/24.3.(1939), s. 12, 13. Prof. Dr. Vasfi Raşit Sevig, "Temizlik” Çocuk, 260/22 İkinci teşrin (1941), s. 1. Çocuk Doktoru, “Temizlik” 1/Nisan (1946), s. 8, 9. "Su ve Tarak Kullanmayan Millet” 66/5 Mart (1925), s. 686, 687. Çocuk Sesi, “Temizliğe İhtiyaç” s. 107/25 Kanun-1 sani (1932), s. 8, 9.

47 Reşit Galip, Köy Muallimleri ile Sağlık Konuşmaları, Muallim Kitapları, 1/İstanbul: Devlet Matbaası, (1933), s. 3-19.

48 G. Ç. Öğretmeni, "Sağlığımızı Koruyalım” Cumhuriyet Çocuğu, 21/Nisan (1938), s. 376. Nihal Yalaza Taluy, "Hayat Bilgisi, Aile Bilgisi: Odamızın Temizliği” Çocuk, 5/9 Mart (1945), s. 3. Nihal Yalaza Taluy, "Hayat Bilgisi, Aile Bilgisi: Odanızı Nasıl Havalandırırsınız?” Çocuk, 7/2 Nisan (1945), s. 3.

49 Süreyya Asım, "Açık Havada Büyüyen Çocuk” Gürbüz Türk Çocuğu, 30/Mart (1929), s.16.

50 Nezahat Nurettin Ege, “Sağlığımızı Koruyalım: Güneş Işı̆̆ının Tılsımı” Doğan Kardeş, 180/9 Mart (1950), s. 2. 51 Çocuk Salnamesi, "Havasızlık Zayıflatır” (1927), s. 104, 105

52 Süreyya Asım, "Kapalı Odalarda Yetişen Yavru” Gürbüz Türk Çocuğu, 31/Nisan (1929), s. 9. Lokman Hekim, "Hekim Ögütleri: Temiz Hava En Önemli Gıdadır” Çocuk Duygusu, 38/26 Haziran (1938), s. 7. Fatma Arif, "Çocuklarınıza Saf Hava Aldırınız Yalnız Sıhhi Tarzda Taşıyınız” Gürbüz Türk Çocuğu, 40/Kanun-1 sani (1930), s. 12, 13. Bu konuda ayrıca bkz. Dr. Ali Rıfat, “Çocuk Sihhati ve Bunun Ehemmiyeti” Gürbüz Türk Çocuğu, 81/ Temmuz (1933), s. 13-18. Dr. Fahriye, “Çocuk Beslenmesi Bakım»" Gürbüz Türk Çocuğu, 99/Şubat (1935), s. 9-13. 53 Mevhibe Ziya, “Açık, Temiz Havanın Kudreti” Gürbüz Türk Çocuğu, 24/Eylül (1928), s. 4, 5.

54 Tok Sözlü, "Vücut Makinesini İyi Kullanmalı" Resimli Mecmua, 42/13 kanun-1 sani (1926), s. 2. Cumhuriyet Çocuğu, "Sağlığımızı Koruyalım” 19(1938) s. 328. Lokman Hekim, "Hekim Öğütleri: Vaktinde ve Tam Uyumak", 
18-20 saat uyumaları, 3-4 yaş civarında günde 12 saat kadar uyumaları gerektiği, ancak yeterince uyuyamayan çocukların, genellikle bir rahatsızlığ olduğu uyarısı yapılır. ${ }^{55}$

Çocukların uykusu sırasında yazın pencerenin içeriyi havalandıracak şekilde açık kalması, kışın ise pencerenin üzerine bir perde ya da paravan geçirilerek, ancak mutlaka çocuğun hava alacağı bir ortamda uyumasının tercih edilmesi gerektiği belirtilir. ${ }^{56}$

Çocuk sağlığı ve bakımı konusunda üzerinde durulan konu başlıklarından biri de çocukların giyimi meselesidir. Çocuk dergilerinde yazı yazan hekimlerin çocuk giysileri konusunda üzerinde durdukları konuların başında çocuk kundakları gelmektedir. Zira hekimler, bebeğe doğduktan hemen sonra giydirilen "kundak" adı verilen giysinin çocuk gelişimi açısından kimi sakıncaları bulunduğunu belirtirler. Buna göre çocukların tamamen kundaklanmasının, çocuğun ruhi ve fiziki gelişimi açısından oldukça zararlı olduğu, bunun yerine ilk aylarda yarım kundak uygulamasının tercih edilmesi, ilk birkaç aydan sonra ise bunun tamamen terk edilmesi gerektiği yönündedir. ${ }^{57}$ Diğer taraftan çocuklara giydirilen giysi kumaşlarının pamuktan olması, giysilerin temizliği, yıkanması, kurutulması konusunun çocuk sağlı̆̆ ve hijyeninin önemli bir parçası olduğu ve bu konuda özenli olunması gerektiği üzerinde durulur. ${ }^{58}$

Çocukların giyimi konusunda, Türk kadınlarının yaptıkları en yaygın hatalardan bir diğerinin de çocuğun çok kalın ve kat kat giydirilmesi konusudur. Ebeveynlerin, bu şekilde çocuğun çok fazla ve kalın giydirilmesi ile hasta olmaktan korunacağ yönünde yanlış bir kanaate sahip oldukları vurgulanır. ${ }^{59}$ Oysaki çok kalın giydirilen ve aşırı 1sıya maruz kalan çocuğun bedeni-bünyesi, soğuğa dayanıksız hale geleceğinden çocuk, hastalıklara daha kolay yakalanacaktır. Dayanıksız bir beden ve bünyeye sahip olan çocuğun soğukla karşılaşması ile bronşit, zatüre, soğuk algınlığı gibi hastalıklara yakalanma olasılığı da artacaktır. Bu yüzden ebeveynlerin çocuğa, içeri ısısına bağlı olarak basit bir fanila giydirmeleri ya da ısıya bağlı olarak giyim seçmeleri önerilir. ${ }^{60} \mathrm{Bu}$ bağlamda çocuğun bulunduğu ortamın ısısı ve iklime uygun olarak giydirilmesi gerektiği konusu giysi ve sıhhat arasında kurulan en önemli bağdır. ${ }^{61}$

Çocuk giysilerinin temizliği ve iklime uygunluğu üzerinde sıklıkla durulurken, giysi konusunun çocuk sağlığı açısından ne derece önemli olduğu vurgulanır. Ancak bu

Çocuk Duygusu, 39/23 Haziran (1938), s. 7.

55 Çocuk Doktoru, "Süt Çocuğu Bakımı: Uyku” 2/Mayıs (1946), s.18-20.

56 Dr. Rıza Tahir Bey, "Çocuk Bakımına Ait Öğütler”, Türk Çocuğu, 14/Teşrin-i Sani (1927), s. 18, 19. Çocuk Salnamesi, "Nasıl Uyumalıdır?" (1927), s. 102, 103. Lokman Hekim, "Hekim Öğütleri: Uykunuza Dikkat Ediniz" Çocuk Duygusu, 20/7 Nisan (1938), s. 12.

57 Dr. Fahriye, “Çocuk Beslenmesi”, Gürbüz Türk Çocuğu, 99/Şubat (1935), s. 9-13. Dr. Reşit Galip, “Çocukları Koruyunuz" Çocuk Haftası, c. 2/23 Nisan (1930), s. 9, 10.

58 Dr. Ali Şükrü Bey, “Çocuk Çamaşırları Nasıl Olmalıdır?” Türk Çocuğu, 6/Mart (1927), s. 8-12.

59 Dr. Agâh Neşet, “Çocuk Giysisi Nasıl Olmalıdır” Gürbüz Türk Çocuğu, 38/Teşrin-i Sani, (1929), s. 12.

60 M. Nihat, "Çocuk Nasıl Giydirilmeli: Bir Doktorun Nasihatleri," Gürbüz Türk Çocuğu, 34/Temmuz, (1929), s. 16, 17. Bu konuda ayrıca bkz. Dr. Ali Şükrü, "Çocuk Çamaşırları”" Çocuk Haftası, c.2/23 Nisan (1930), s. 91-94. 61 Nezahat Nurettin Ege, "Sağlığımızı Koruyalım: Niçin Mevsime Göre Giyiniriz?” Doğan Kardeş, 186/20 Nisan (1950), s. 5. M. Nihat, “Çocuk Nasıl Giydirilmeli: Bir Doktorun Nasihatleri,” Gürbüz Türk Çocuğu, 34/Temmuz (1929), s. 16, 17. Gürbüz Türk Çocuğu, "Yazın Ne Giydirmeli?” 35/Ağustos (1929), s. 17. 
burada bahsi geçen giyimden kast edilen temelde çocuğa "lüks" ve "pahalı giysiler" giydirilmesi değildir. Çocuk giysilerinde dikkat edilmesi gereken hususun; giysilerin temiz, düzgün ve özenli olmasıdır. Bu çerçevede çocukların giyimlerine fazla harcama yapılmaması ve çocuğun iki giysisinin olması yeterli görülmektedir. $\mathrm{Bu}$ giysilerden birinin okulda, diğerinin ise tatil günlerinde, hafta sonlarında ve ziyaretlerde giymesinin uygunluğu ifade edilir. ${ }^{62}$ Çocuk dergilerinde, çocukların giysi meselesinde de somutlaşan tasarruf ve israftan kaçınma söylemleri, bize dönemin ekonomik koşullarını hatırlatmaktadır. Zira bahsi geçen anlatılarda, iki savaş arası döneminin zorlu ekonomik koşullarında, tüketim alışkanlıkları ve genel olarak tüketim kültürü konusunda bugünden farklı olarak, daha az tüketmenin daha makbul olduğu vurgusu ağırlık kazanmaktadır. Bu çerçevede çocuk giysileri konusundan hareketle söylemek gerekirse, öne çıkarılacak düşünce tüketimin miktarının fazla olmasından ziyade, bunun sınırlı tutulması, ancak çocuğun sağlığı, bakımı, temizliği, merkeze alınarak bu konuda annelerin, ebeveynlerin özenli olması gerektiğidir.

\section{Çocuk Beslenmesi}

Erken cumhuriyet dönemi çocuk dergilerinde, çocuk bakımı konulu yazıların, önemli bir bölümü çocuğun beslenmesi konusunu içermektedir. Zira ele alınan dönem içerisinde, özellikle $20^{\prime} l i$ ve $30^{\prime} l u$ yıllarda doğan çocukların bir kısmı ilk birkaç yıl içerisinde hayatını kaybetmiştir. Konu üzerine yapılan araştırmalarda çocukların hayatlarını kaybetmesinin temel nedenleri arasında salgın hastalıklar ve çocuk bakımı konusundaki yetersizlikler bulunmaktadır. ${ }^{63} \mathrm{Bu}$ nedenle erken Cumhuriyet döneminde yayımlanan çocuk dergilerinde, (özellikle Gürbüz Türk Çocuğu) çocuk bakımı konusu oldukça ayrıntılı bir biçimde ele alınmış ve konuya dair akla gelebilecek her konuda detaylı yazılar yazılmıştır. Çocuk bakımı konusunda dönemin hekimlerinin üzerinde en fazla durdukları başlık, çocuk beslenmesidir. Zira çocuk bakımı sürecinde çocukların hastalanması, çeşitli rahatsızlıklar yaşamalarının en nihayetinde çocukların ölümüne kadar varan hataların yapıldı ̆̆ı böyle bir konuda, dönemin hekimleri, sahip oldukları bilimsel bilgiler ışığında yazdıkları yazılar ve verdikleri konferanslarla halka ulaşmaya çalışmışlardır. ${ }^{64}$ Bu konudaki anlatılar, çocuğun henüz doğmadan önceki süreci ile başlamaktadır. Annenin bu süreçte sağlıklı ve dengeli beslenmesinin çocuğun gelişimi açısından ne derece önemli olduğu sıkça vurgulanır. ${ }^{65} \mathrm{Bu}$ bağlamda çocuk beslenmesi konusunda en sık yapılan hataların başında, çocuğun doğumunu takip eden ilk dakikalarda, çocuğa hemen anne sütü verilmesi gelmektedir. ${ }^{66}$ Bunun dışında çocuk beslenmesi konusunda yapılan hatalardan bir diğerinin de çocuğun dünyaya geldikten sonraki ilk haftalar ve aylarda anne sütü dışında su ve diğer gıdalar ile beslenmeye çalışılmasıdır. Zira dönemin hekimleri, çocuk beslenmesi konusunda yazdıkları yazılarda, sıklıkla çocukların 5

62 Hikmet Şevki, “Çocuğun Telebbüs Tarz””, Gürbüz Türk Çocuğu, 30/Mart (1929), s. 10, 11.

63 Dr. Fuad Umay, “Çocuklarımızın Yüzde Yetmişi Ölüyor.” Türk Çocuğu, 5/Mayıs, (1927), s. 1-3.

64 Resimli Мecmua, “Vücut Makinesi Nasıl İşler Kalır?”, 50/19 Mayıs (1927), s. 14. Çocuk Salnamesi, “Çocuklara Bakım Yolları" (1927): 60.

65 Dr. Rıza Tahir Bey, "Çocuk Bakımına” s. 18, 19. Çocuk Duygusu, “Çocukların Gıda Meselesi: Bir Fransız Doktor Neler Söylüyor” 33/12 Mayıs, (1938), s. 2.

66 Dr. Fahriye, “Çocuk Beslenmesi (1)” Gürbüz Türk Çocuğu, 36/İkinci teşrin (1936), s. 11-15. 
ya da 6. aya kadar sadece süt ile beslenmeleri gerektiğini israrla vurgularlar. ${ }^{67}$ Anne sütünün, bebeğin vücudundaki pek çok mikrop ve zararlı bakteriyi etkisiz hale getirdiği bu yanıyla annelerin, çocuklarını ilk altı ayda sadece anne sütüyle, 6. Aydan sonra ise anne sütünün yanında diğer gidalar ile beslemeleri gerektiği üzerinde durulur. ${ }^{68}$ Annelerin ortalama olarak dört saatte bir yeteri kadar çocuğu beslemeleri gerektiği ancak anne sütünün yetersiz olduğu hallerde, doktor tavsiyesi ile önerilen miktarda ek gıda verilmesi gerektiği belirtilir. Anne sütü yok ise bu noktada koyun, kısrak, manda, keçi sütünün iyice kaynatılması ve çok yağlı olan inek sütünün ise su ile seyreltilerek verilebileceği önerilir. Ancak anne sütüne en yakın sütün keçi sütü olduğu, sütü olmayan annelerin çocuklarını keçi sütü ile besleyebilecekleri belirtilirken, ${ }^{69}$ keçi sütü, aynı zamanda verem mikrobu taşımayan tek süt türü olarak kabul edilmiştir. Bu yüzden kaynatılmadan da rahatlıkla içilebileceğ $i^{70}$ ancak çocuklara verilecek olan sütlerin sıhhi olup olmadıklarının, devlet tarafından denetiminin de önemli olduğu vurgulanır. ${ }^{71}$

Beslenme konusunda üzerinde en fazla durulan husus, çocuğun mutlaka anne sütü ile beslenmesi gerektiğidir. Zira anne sütünün bir tür doğal ilaç olduğu ve çocuğu hastalıklardan koruyan, oldukça hayati bir besin kaynağı olduğudur. ${ }^{72}$ Anne sütü ile beslenen çocuklarda ölüm tehlikesinin daha az olduğu, kemik ve diş hastalıklarına yakalanma olasılıklarının daha düşük olduğu vurgulanır. Çocuğun, sağlıklı bir şekilde yetişmesi konusunda bu derece önemsenen anne sütü, çocuğun doğumunu takip eden süreçte mümkün olmamış ise çocuğun anne sütünden yararlanması için "sütanne" ile beslenmesi önerilir. Bununla beraber ailelere, çocukların sağlıklı beslenmeleri konusunda önerilen sütannenin, seçimi konusuna çok dikkat etmeleri, zira seçilecek olan sütannenin gerekeli sağlık tetkiklerinin mutlaka yapılmış olması gerektiği vurgulanır. ${ }^{73}$ Ancak incelenen dönem içerisinde oldukça yaygın bir uygulama olan "sütana, sütnine, mürebbiye, dadılık" geleneği çerçevesinde, insanların bireysel referanslarından hareket ederek belli kimselere ulaştıkları ve ancak devlet denetiminin olmadığı böyle bir sürecin, temelde çocukların sağlıklarını tehdit eden olasılıkları da içerisinde barındırdığıdır. Özellikle "sütannelik" gibi insanların kendi

67 Emin Şükrü, “Çocuk Yetiştirmek Büyük Bir Sanattır” Türk Çocuğu, 11/Temmuz (1927), s. 12-14. Bu konuda ayrıca bkz. Ali Vahit, "Bebek Nasıl Beslenir (1)” Gürbüz Türk Çocuğu, 54 /Mart (1931), s. 12-15. Dr. Ali Rifat, Çocuk Sıhhati ve Bunun Ehemmiyeti, Gürbüz Türk Çocuğu, 81 /Temmuz (1933), s. 13-18. Dr. Kilisli Rifat, "Doğuştan Sonraki Gelişme" Gürbüz Türk Çocuğu, s. 99 (Şubat 1935): 24-32. Dr. W.Feer, çev., Dr. Cihat Gürson, "Çocuğu Nasıl Beslemeliyiz" Çocuk Doktoru, 3/Haziran (1946), s. 2-4.

68 Çocuk Bakımı, "Süt Çocuklarında Süt Verme, Emzirme” 25-26/30-15 Nisan (1934), s. 51, 52.

69 “Çocuklara Hangi Gıda İntihab Olunmalıdır?” Türk Çocuğu, 11/Temmuz (1927), s. 25-27. Aynı yönde bilgi için bkz. Dr. Fahriye, "Çocuk Beslenmesi (1)”, 11-15. Dr. W.Feer, çev., Dr. Cihat Gürson, "Çocuklarımızı Nasıl Beslemeliyiz” Çocuk Doktoru, 4/Temmuz (1946), s. 2-3. Mehmed Nuri, "Çocukların Gıdası” Hayat ve Sihhat, 1 Nisan (1921) s. 17-21. Dr. Fahriye, “Ana Sütü” Gürbüz Türk Çocuğu, 97/Birinci kanun (1934), s. 9-12. Çocuk Salnamesi, "İdare-i Sıhhiye" (1927), s. 134, 135. Emin Şükrü "Anne Sütünden Mahrum Olan Çocukları Besleme Sanatı” Türk Çocuğu, 12/1 Eylül (1927), s. 6-9. Aynı yönde bilgi için bkz. Dr. Rıza Tahir Bey, "Çocuk Bakımına Ait Öğütler" Türk Çocuğu, 14/Teşrin-i sani (1927), s. 18, 19.

70 Gürbüz Türk Çocuğu, “Keçi Sütü”, 34/Temmuz (1929), s. 12.

71 Çocuk Salnamesi, “İdare-i Sihhiye” (1927), s. 134, 135.

72 Çocuk Salnamesi, “Çocukta Yürümek Kabiliyeti Yiyeceğe Tabidir,” “Anne Sütü,” (1927), s. 63, 64.

73 Türk Çocuğu, “Çocuk Bakımına Ait Öğütler: Çocuk Beslemek”, 17/Şubat (1928), s. 5, 6. Gürbüz Türk Çocuğu, "Çocuk Bakımına Ait Öğütler: Annelere” 20/Mayıs (1928), s. 6. Dr. Fahriye, Ana Sütü, Gürbüz Türk Çocuğu, 97/ Birinci kanun (1934), s. 9-12. 
bireysel çabaları çerçevesinde edindikleri bu hizmetin, pek çok acı tecrübeyi de içerisinde barındırdığı ortaya konur. Bu konuda dergi yazarları, çocuklar için ülkede pek çok alanda hizmet veren önemli kurumlardan biri olan Himaye-i Etfal Cemiyetinin kurduğu "Süt Damlaları" "Ana Kucakları" "Ana Yuvaları" bulunduğu, bu kurumlardan hizmet almanın da mümkün olduğundan bahsederler. ${ }^{74}$

Erken cumhuriyet döneminde, çocuğun yaşamında kritik olan ilk yaşları geçirdiği evreden sonraki okul çağı sürecinde de beslenmesinin önemli olduğu vurgulanır. İncelenen dergilerde çocukların dengeli ve yeterli beslenmesinin özellikle önemsendiği böyle bir dönemde okul çağına gelebilmiş olan çocukların beslenmelerinin yetersiz olduğu tespit edilmiştir. ${ }^{75}$ Öyle ki TBMM üyelerinden bir mebus, tahsisatının bir kısmını, okullardaki çocuklara gıda yardımı sağlayan kurumlara verilmesi için başvuruda bulunmuştur. Ayrıca bu süreçte okul çağındaki çocukların, beslenme, gıda ihtiyacı için toplumun duyarlılığını arttırmak ve bu konuda dayanışmayı sağlamak yönünde de telkinlerde bulunulmuştur. ${ }^{76}$ Okul öncesi ve okul çağ lişiminde ve hastalıklardan korunmasında beslenmenin çok önemli bir yeri olduğu, ancak bu yaşlardaki çocukların yeterince beslenemedikleri dolayısıyla bir "Süt Teşkilatı" meselesinin bir an önce hayata geçmesi ve okullardaki çocuklara süt dağıtılmasının oldukça yararlı olacağı belirtilir. Okul çocuklarının, beslenme gereksinimleri için ortaya konan bir diğer öneri de çocukların öğle yemeklerinin, Kızılay’ın aş ocaklarında pişirdikleri yemeklerden sağlanması yönündedir. ${ }^{77}$

Bunun dışında ilk çocukluk yıllarında çocukların beslenmesinin çok önemli olduğu, çocuk bedenin bir ağaca benzetildiği ve ilk çocukluk yıllarında iyi beslenmeyen çocukların, "zayıf ve cllız ağaçlar gibi" olacağı, çocukların çok değil ama yeterli ve dengeli beslenmelerinin önemli olduğu vurgulanır. ${ }^{78}$ Ancak bunun yanında beslenme konusundaki sıhhatin "balık yağı ve kuvvet şurubu ile değil" programl ve sağlıklı "bol yemek" "bol gıda" alarak gerçekleştiğini belirten söylemler de bulunmaktadır."

Çocuk beslenmesi konusunda ailelerin dikkat etmesi gereken konulardan bir diğerinin de beslenmenin, çocuğun yalnızca fiziksel gelişimini değil, aynı zamanda zekâ gelişimini de olumlu/olumsuz yönde etkileyebileceğidir. Zira dergilerde sağlık konusunda genel olarak referans kaynağı olarak Batıda yapılan araştırmalar gösterilmiştir. Çocukların zekâ gelişimleri konusunda da beslenme ve zekânın gelişimi üzerine yapılan araştırmaların sonuçlarından hareket edilerek, okuyuculara bu konuda bilgi verilir. Farklı değişkenlerle, yapılan pek çok tetkik yıllarca devam etmiş,

74 Mithat Ömer, "Sütanaya, Dadıya, Mürebbiye, Hizmetçiye Dair” Gürbüz Türk Çocuğu, s. 31/Nisan (1929), s. 3, 4. Bu konuda ayrıca bkz. Dr. Fahriye, "Sütnine ile Besleme”, Gürbüz Türk Çocuğu, 98/İkinci kanun (1935), s. 9-11. 75 Çocuk Salnamesi, “Mekteplerde Fakir Küçük Çocukların İaşesi” (1927), s. 131.

76 Ahmet Rasim, “Gıdasız Çocuklar” Türk Çocŭ̆u, 6/Mart (1927), s. 14, 15.

77 Dr. Şemsi Mutver, "En Büyük Milli Davamı"” Çocuk Doktoru, 7/Ekim (1946), s. 2-5.

78 Hikmet Şevki, “Amcamın Köşesi, Çocuğun Gıdası” Gürbüz Türk Çocuğu, s.19/Nisan (1928), s. 6-7. Bu konuda ayrıca bkz. Dr. Ali Vahit, “Bebek Ne İle Beslenir II?” Gürbüz Türk Çocuğu, 56/Mayıs (1931), s. 21-23. Bahtiyar Demirağ, “Türkiyede Çocuk Beslenmesi Meselesi” Çocuk Doktoru, 6/Eylül (1946), s. 2-4.

79 Cumhuriyet Çocuğu, "Sağlığımızı Koruyalım” 19(1938), s. 328. Emin Şükrü, “Çocuk Yetiştirmek Büyütmek” s. 12-14. 
sonuçta vitaminlerin, çocukların tüm gelişim sürecinde çok önemli bir yeri olduğu vurgulanmıştır. ${ }^{80}$

\section{Erken Cumhuriyet Dönemi Çocuk Dergilerinde İdealize Edilen Çocuk Bedeni}

İncelenen dönemin çocuk dergilerinde yer alan sağlık köşelerinde, toplumun, ailelerin, "şişmanlığı" ya da kilolu olmayı genellikle bir sağlık sorunu olarak görmedikleri, hatta bunun aksine, toplumdaki genel kanının, dolgun vücutlu ya da kilolu bedenlere sahip olmanın, görece sağlıklı olmakla eşdeğer tutulduğu, hatta yüceltildiği bir anlayıştan bahsedilebilinir. ${ }^{81}$ Toplumun genel kanısının bu şekilde belirmesinin temelinde, dolgun ya da şişman olmayan bir bedenin zayıf, çelimsiz, güçsüz ya hastalıklı ya da hasta olmaya yatkın olması anlayışı bulunmaktadır.

Buna karşın, ele alınan dönemin çocuk dergilerinde yazı yazan hekimlerin, idealize ettiği beden yapısı, halkın idealize ettiği beden anlayışından farklıdır. Zira dönemin hekimlerinin anlatılarında "şişmanlığın", sağlıklı ve istenilen bir durum olarak kabul edilmediği anlaşılmaktadır. Şişman olan çocukların hızlı ve atik olamadıkları, genellikle "hantal ve yavaş oldukları, benizlerinin sarı ve sıhhatsiz" bir görünümde olduğu belirtilirken, şişmanlığı doğuran şeyin ise genellikle sağlıksız ve dengesiz beslenme olduğu tespiti yapılır. ${ }^{82}$ Şişman çocukların, kimi hastalıklara daha çabuk yakalanacakları ve ilerleyen yaşlarda da pek çok hastalık ile karşılaşma olasılıklarının daha yüksek olduğu ortaya konurken, çocukların ideal kilolarının, boy ve kilo arasındaki orantı ile ölçülebileceğidir. ${ }^{83}$ Bunu ölçmenin en pratik yolunun ise dönemin hem sağlık merkezlerinde, hem de okullarında, bu konuda hazırlanmış olan tablolarda verilen standartlar olduğu, bu standartların çok altında ve çok üstünde olanların zayıf ya da şişman olarak tanımlanabileceği yönündedir. ${ }^{84}$ Dolayısıyla dönemin hekimleri, halkın ve halkın içerisinden geldiği geleneksel ideal beden tanımlamalarından farklılaşarak, modern dünyanın kabul ettiği standartları esas almışlardır. Erken Cumhuriyet döneminde, özellikle kırklı yıllar ve sonrası süreçte, aslında toplumun da genel kabulünde dönemin hekimlerinin dolayısıyla da rejimin öngördüğü, idealize ettiği bedenler temelde modern dünyanın kabul ettiği standartlar üzerinden şekillenecektir.

80 Asrın Çocuk, "Dördüncü Sinıflara Tabiat Bilgisi: Vitaminler” 24/13 Nisan (1940), s. 4. Gürbüz Türk Çocuğu, "Çocuğun Zekâsı Gıdasına Bağlıdır", 34/Temmuz (1929), s. 9-11. Prof. Dr. Sait Cemil Bey, "Besi İşinde Son Hakikatler” Gürbüz Türk Çocuğu, 38/Teşrin-i sani (1929), 16, 17. Lokman Hekim, "Çocukların Gıda Meselesi: Bir Fransız Doktor Neler Söylüyor” Çocuk Duygusu, 33/12 Mayıs (1938), s. 1. Gürbüz Türk Çocuğu, "Vitamin: Çocuğun Gıdasından Vitamini Azaltmak Onu Ölüme Mahkûm Etmektir”, 56/Mayıs (1931); s. 9,10. Çocuk Sesi, "Sağlık Bilgisi: Vitaminler" 362/30. İkinci teşrin, (1936), s. 19. Doğan Kardeş, "Vitamin, Vitamin” 33/1 Aralık (1946), s.16. Dr. Feridun Neşet Bey, "Sıhhi Metinler: Vücudumuz" Yeni Yol, 29/22 Mart (1924), s. 67-68. Çocuk Doktoru, "Vitaminler" 4/Temmuz (1946), s. 26-27. Asrın Çocuk, "Dördüncü Sınıflara Tabiat Bilgisi: Besinlerimiz" 8/23 Birinci kanun (1939), s. 4. Gürbüz Türk Çocuğu, Çocuklara Ne Yedirmeli? (İngilizceden çeviren M.F) 52/ İkinci kanun (1931), s. 6-7.

81 Dr. Fahriye, "Bol Beslenme (1)” Gürbüz Türk Çocuğu, 108/Birinci kanun (1935), s. 11-15. Dr. Fahriye, "Bol Beslenme (2)” Çocuk,1/İkinci kanun (1936), s. 14, 15. Dr. Fahriye, "Bol Beslenme (3)” Çocuk, 2/Şubat (1936), s. 14, 15. Yeni Yol, "Şişmanlamak İçin Yeni Bir Usul” 45/9 Teşrin-i evvel, (1924), s. 236-239.

82 Resimli Dünya, “Nasıl Zayıflamalı, Nasıl Şişmanlamalı?” 1/Kanun-1 evvel, (1924), s. 15.

83 Çocuk Bakımı, "Büyümek: Beslenme İhtiyacı” 22-23/15-31 Mart (1934), s. 17-19.

84 Fatma Reşid, “Şişman Çocuk Sihhatlimidir?” Türk Çocuğu, 13/1 Teşrin-i evvel (1927), s. 13. 
Dönemin idealize edilen beden standartlarından da anlaşıldığı üzere, Cumhuriyetin ideal bedenine sahip çocuğu, hızlı hareket edebilen, güçlü, çevik, atik, ne çok şişman ve hantal ne de zayıf ve çelimsiz olmamalıdır. Bu anlatıda erkek çocuklar ileride yurdu savunacak birer asker ve tarlada, fabrikada çalışabilecek güçlü ve dinamik bedenlere sahip olacak özelliklerle tahayyül edilmişlerdir. Bunun yanında kadın bedenleri ise gelecekte yurdun geleceğini emanet edecek, sağlıklı çocuklar dünyaya getirecek ve onları sağlıklı bir şekilde büyütecek güçlü, dayanıklı bedenlere sahip olarak resmedilmişlerdir.

Ancak yirmili ve otuzlu yıllarda idealize edilen bahsi geçen beden formu sürekli değildir. Zira yirmili yıllar, savaşlar sonrası sürecin hem azalan nüfusunu yeniden arttırmak, hem ekonomik yoksunluklar ve hastalıkların pençesinde olan bir halkı yeniden sağlamlaştırmak, çoğaltmak amacıyla mümkün olan en dirençli, gürbüz ve güçlü beden söylemlerinden hareket ederek oluşturulmuştur. Ancak kırkılı yılların ikinci yarısından itibaren, artık ülke için savaş ihtimallerinin ortadan kalktığı, salgın hastalıkların önemli oranda azaldığı yeni bir evreyi ifade etmiştir. Dolayısıyla hem siyasal ve askeri konjonktürün, hem de görece ekonomik ve sosyal refahın artmasıyla beraber yalnızca hekimlerin ve sağlık görevlilerinin değil, halkın da bakışında idealize edilen beden formu görece bir değişim geçirmiştir. Bu bağlamda kırklı yıllarda yayımlanan çocuk dergilerinde, çocuğun bakımı, beslenmesi ve salgın hastalıklarla mücadele söylemi, yerini daha çok sağlıklı ve dengeli beslenme, spor ve jimnastik ${ }^{85}$ ve en nihayetinde kilolu, "şişman" olmayan, estetik bir beden anlayışına bırakmıştır. ${ }^{86}$

\section{Sonuç}

Girişte de üzerinde durulduğu gibi 19 ve 20. Yüzyılda modern devlet yapılarının yükselmesine bağlı olarak ulus-devletin sınırlarının korunması, savunulması ve ekonomik kalkınma yoluyla güçlendirilmesi gibi amaçlar çerçevesinde insan faktörü, hele ki üretken durumda olan neslin bedeni, sağlığı, üretkenlik kapasitesi devletler için gittikçe önem kazanan bir alana dönüşmüştür. Zira modern devlet yapılarında devletin siyasal ve ekonomik alandaki gücü büyük oranda sahip olduğu nüfusun niteliği, üretkenlik kapasitesi ve gücü ile eş değerde görülmüştür. Bu nedenle modern iktidarlar, sahip oldukları nüfusu daha çocukluk yıllarından itibaren sağlıklı, güçlü ve dayanıklı olarak yetiştirme amacı gütmüşlerdir. Bu bağlamda modern iktidar yapıları, sahip oldukları biyo politika perspektifi ile nüfusu düzenleme sorumluluğu çerçevesinde toplumların gelecek ekonomik, sosyal, siyasal refahları, güvenlikleri açısından tüm bu alanın iktidar mekanizması tarafından “düzenlenmesini” gerçekleştirmeye çalışmışlardır. ${ }^{87}$

Modern devlet yapılarının bahsi geçen “düzenleyici denetim mekanizmaları” çerçevesinde odaklandıkları temel konuların başında, sahip olunan nüfusun, doğum,

85 Doğan Kardeş, “Güzel Vücutlu Olacağız” c.2, 20/15 Mayıs (1946), s. 1 Dr. Süreyya Hidayet, "Şişmanlık ve Bundan Korunmak Kurtulmak" Sihhat Almanakı, (İstanbul: Kader Matbaası, 1370/1951) 870. Çocuk Sesi, "Mehlika Ablanın Nasihatleri" c.7, 69/7 Mayıs (1931), s. 13.

86 Mazhar Osman, "Hergünkü Yemeklerimizin Beslenme Derecesi, İnsana Ne Kadar Yemek Lazım - İnsan Nasıl Zayıflamalı - Nasıl Şişmanlamalı” Sihhat Almanakı, (İstanbul: Kader Matbaası, 1370/1951), s. 88-92.

87 Foucault, Cinselliğin Tarihi, 43. 
ölüm, yaşam süresi, doğurganlık oranları, genel sağlık düzeyi, salgın hastalıklar, hastalıkların sıklığı, hijyen ve beslenme gibi konular gelmekteydi. ${ }^{88}$

Türkiye tarihinde, Cumhuriyet döneminde gittikçe daha fazla güçlenen modern devlet yapısı diğer örneklerinde olduğu gibi ulusal sınırların ve rejimin korunması, savunulması, ekonomik üretkenlik ve kalkınma çabaları çerçevesinde sahip olunan nüfusun her anlamda nitelikli, sağlıklı, üretken ve güçlü olmasını amaçlamıştır.

Cumhuriyet yönetimi, geçmiş dönemde yapılan savaşlar, salgın hastalıklar ve yetersiz koşulların tetiklediği nedenlerle nüfusunun önemli bir kısmını yitirmiştir. Elde kalan ve genellikle hasta, sağlıksız, bakımsız ve yetersiz olan nüfusun güçlendirilmesi çabaları çerçevesinde üzerinde titizlikle durulan konuların başında; sağlıklı doğum oranlarının arttırılması, özellikle çocuk ölümlerinin azaltılması ile sağlıklı ve güçlü yeni bir nüfusun yeşertilmesi gelmekteydi. Bu bağlamda ülke nüfusunun arttırılması, dolayısıyla sağlıklı doğum, çocuk bakımı ve hastalıklardan korunma konusu, devletin odaklandığı ve üzerine politika geliştirdiği temel konuların başında yer almıştır.

Cumhuriyetin ilk yıllarında, eldeki oldukça yetersiz araçlarla sahip olunan nüfusa ulaşmanın ve onları çeşitli konularda bilgilendirmenin güçlügü aşikârdır. Böyle bir ortamda sahip olunan nüfusa ulaşmak, bahsi geçen konular çerçevesinde neler yapılması, nasıl yapılması gerektiğini anlatmanın en pratik yollarından birinin de popüler çocuk yayınları olduğu kabul edilmiştir.

Zira çocuk dergileri yalnızca çocukların okudukları dergiler olmaktan ziyade tüm ailenin özellikle de annelerin ilgi odağında olması vesilesiyle anne ve çocuk eksenli bir yayın politikası izlemişlerdir. Çocuk dergilerinde çocuktan, çocuk bakımından, çocuğun yaşatılması ve sağlıklı hale getirilmesinden sorumlu asıl kişinin anne olduğu, bu yanıyla annelerin bir taraftan "kutsal" bir görevi üstlendiği, diğer taraftan da sağlıklı çocuk yetiştirmenin bir "sanat" olduğu söylemi geliştirilerek, konun devlet ve toplum katında ne derece önem kazandığ 1 anlatılmaya çalışılmıştır. Annelerin hem bu kutsal görevleri, hem de kadınlıkla özdeşleştirilen sağlıklı çocuk yetiştirmeleri "sanat" olarak adlandırılarak dönemin makbul kadının temel görevleri de tanımlanmiştır.

Zira ele alınan metinlerde, çocuğun yalnızca içine doğduğu aileye ait olmadığı, çocuğun, aynı zamanda devletin ve milletin olduğu söylemi geliştirilerek, çocuk meselesinin devlet açısından ne derece önemsendiği ortaya konuştur. Erken Cumhuriyet döneminde, çocuk bakımının aynı zamanda nüfus politikalarının da temel belirleyenleri arasında olduğu düşünülürse, ele alınan konunun, devlet katında çok boyutlu olarak ele alındığı, değerlendirildiği ve üzerine politika geliştirdiğinden bahsedilebilinir.

Erken Cumhuriyet döneminde devlet katında bu derece önemsenen çocuk bakımı ve sağlığı konusu çerçevesinde ortaya konan tüm bilgi ve söylemin temel kaynağ1, bilimselliği sıklıkla dillendirilen Batı referanslı yöntem ve uygulamalardır. Çocuk 
dergilerinde bu yönde sıklıkla özellikle Almanya örneğinden hareketle çocuk bakımı konusundaki yöntem ve uygulamalar konu edilmiştir.

Dönem içerisinde nüfusu arttırma çabalarının odağında olan başlıca konu çocuk ölümlerinin önüne geçebilme ve doğan çocukları sağlıklı bir şekilde hayatta tutma çabasıdır. Bu bağlamda henüz gebelik döneminde başlayarak, doğum ve sonrasındaki tüm süreç oldukça ayrıntılı bir şekilde dönemin bilimsel kavrayışı ve yöntemleri esas alınarak anlatılmaya çalışılmıştır. Bu anlatıda sıklıkla vurgulanan konu başlıkları arasında; sağlıklı doğum yöntemleri, doğum sonrasında çocuğun bakımı, beslenmesi, temizliği, hijyeni, giysileri ve uyku düzeni gibi çocuğun sağlığı ile ilgili tüm ayrıntılar konu edilmiştir.

$\mathrm{Bu}$ anlatılarda sıklıkla geçmiş toplum yapısından süregelen, çocuk bakımı ve sağlığı konusunda genellikle kulaktan dolma, bilimsellikten uzak, kimi zaman hurafelere dayalı, hatalı bilgi ve yöntemlerin terk edilmesi, bilimsel yöntem ve uygulamaların öğrenilmesi, seferberlik halinde sıklıkla teşvik ve telkin edilmiştir. Çocuk dergilerinde ailelere özellikle de çocuk bakımından sorumlu olan annelere dönük olarak yazılan yazılar ve bu çerçevede ortaya konanlar ile sağlıklı bir çocuğa sahip olmanın tüm incelikleri adım adım anlatılmıştır.

Bahsi geçen anlatılarda bebeklik döneminden başlayarak, ilk çocukluk ve okul yıllarında kazanılan bakım, beslenme, uyku, temizlik, hijyen gibi alışkanlıklarının, gelecek yaşamlarında da çocukların gündelik yaşam alışkanlıklarının temellerini oluşturması amaçlanmıştır. Böylece Cumhuriyetin idealize ettiği ve modern toplumların gündelik yaşam alışkanlıklarını oluşturan, bakım, beslenme, giyim, temizlik, hijyen kurallarını bilen çocukların gelecekte sağlıklı ve salgın hastalıklardan arınmış bir toplumun temellerini oluşturması yönünde önemli adımlar atılmıştır.

Ele alınan dönem içerisinde yayımlanan çocuk dergilerinde ortaya konan tüm bu bakım, beslenme, sağlık, temizlik, hijyen söylemlerinden hareketle idealize edilen bir beden yapısı ortaya konmuştur. Dönemin idealize edilen beden standartlarında da anlaşıldığı üzere, Cumhuriyetin ideal bedenine sahip çocuğu, hızlı hareket edebilen, güçlü, çevik, atik, ne çok şişman ve hantal ne de zayıf ve çelimsiz olmamalıdır. $\mathrm{Bu}$ anlatıda erkek çocuklar ileride yurdu savunacak birer asker ve tarlada, fabrikada çalışabilecek güçlü ve dinamik bedenlere sahip olacak özelliklerle tahayyül edilmişlerdir. Bunun yanında kadın bedenleri ise gelecekte yurdun geleceğini emanet edecek, sağlıklı çocuklar dünyaya getirecek ve onları sağlıklı bir şekilde büyütecek güçlü, dayanıklı bedenlere sahip olarak resmedilmişlerdir.

Böylece erken Cumhuriyet dönemi çocuk dergilerinde çocuk bakımı ve sağlığı çerçevesinde ortaya konan anlatı çerçevesinde Cumhuriyetin idealize edilen bireyinin sahip olması gereken beslenme, uyku, temizlik, hijyen gibi alışkanlıklar ile resmedilirken diğer taraftan da tüm bu söylemlerle idealize edilen bedenlerin inşasına çabalanmıştır. 


\section{Kaynakça}

Ahmet Rasim. “Gıdasız Çocuklar”. Türk Çocuğu. 6/Mart (1927): 14, 15.

Akın, Veysi. Bir Devrin Cemiyet Adamı: Doktor Fuad Umay. Ankara: Atatürk Araştırma Merkezi, 2000.

Ali Şükrü Bey. “Doğacak Çocuklar İçin Sıhhi Ne Gibi Hazırlık Yapılmalıdır?”. Gürbüz Türk Çocŭ̆u. 5/Şubat (1927): 4-7.

Ali Vahit. “Bebek Nasıl Beslenir (1)”. Gürbüz Türk Çocuğu. 54 /Mart (1931): 12-15.

Asrın Çocuk. "Dördüncü Sınıflara Tabiat Bilgisi: Besinlerimiz". 8/23 Birinci kanun (1939): 4.

Asrın Çocuk. "Dördüncü Sınıflara Tabiat Bilgisi: Vitaminler”. 24/13 Nisan (1940): 4. Ateş. “Güneş Büyük Düşman”. 28/7 Haziran (1938): 6.

Cumhuriyet Çocuğu. “Canını Seven Her İnsanın Bilmesi ve Uyması Gereken Kurallar”. 25/20 Nisan (1939): 419.

Cumhuriyet Çocuğu. "Sağlığımızı Koruyalım”. 19/Şubat (1938): 328.

Çelik, Kemal. “Atatürk Dönemi C.H.P ve Hükümet Programlarında Sağlık” Atatürk Dönemi Sağlık Tarihi Kongresi (1920-1938) Bildiriler. Editörler: Mustafa Mutluer, Eren Akçiçek, İzmir: Ege Üniversitesi Basımevi, 2009. 296-305.

Çocuk Bakımı. "Büyümek: Beslenme İhtiyacı”. 22-23/15-31 Mart (1934):17-19.

Çocuk Bakımı. “Süt Çocuklarında Süt Verme, Emzirme”. 25-26/30-15 Nisan (1934): $51,52$.

Çocuk Doktoru. “Süt Çocuğu Bakımı: Uyku”. 2/Mayıs (1946): 18-20.

Çocuk Doktoru. “Süt Çocuğu Bakımı”.1/Nisan (1946): 18, 19.

Çocuk Doktoru. “Temizlik”. 1/Nisan (1946): 8, 9.

Çocuk Doktoru. "Vitaminler”. 4/Temmuz (1946): 26, 27.

Çocuk Duygusu. "Çocukların Gıda Meselesi: Bir Fransız Doktor Neler Söylüyor”. 33/12 Mayıs, (1938): 2.

Çocuk Salnamesi. “Annelerin Sihhati Umumun Sihhatı”. (1927): 129, 130.

Çocuk Salnamesi. "Çocuklara Bakım Yolları”. (1927): 60.

Çocuk Salnamesi. “Çocuklarınıza İyi Bakınız”. (1927): 32.

Çocuk Salnamesi. "Çocukta Yürümek Kabiliyeti Yiyeceğe Tabidir, Anne Sütü”. (1927): 63, 64.

Çocuk Salnamesi. "Havasızlık Zayıflatır”. (1927): 104, 105

Çocuk Salnamesi. "İdare-i Sihhiye”. (1927): 134, 135.

Çocuk Salnamesi. "Mekteplerde Fakir Küçük Çocukların İaşesi”. (1927): 131.

Çocuk Salnamesi. “Nasıl Uyumalıdır?”. (1927): 102, 103.

Çocuk Salnamesi. “Sağlığınızı Muhafaza Etmek İsterimsiniz?”. (1927): 87-88.

Çocuk Salnamesi."Tabibi Beklerken”. (1927): 26-27.

Çocuk Sesi. "Mehlika Ablanın Nasihatleri”. 69/7 Mayıs (1931): 13.

Çocuk Sesi. “Sağlık Bilgisi: Vitaminler”. 362/30. İkinci teşrin, (1936): 19.

Çocuk Sesi. “Temizliğe İhtiyaç”. 107/25 Kanun-1 sani (1932): 8, 9. 
Demirağ, Bahtiyar. "Türkiye'de Çocuk Beslenmesi Meselesi”. Çocuk Doktoru, 6/ Eylül (1946): 2-4.

Doğan Kardeş. “Güzel Vücutlu Olacağız". c.2, 20/15 Mayıs (1946):1

Doğan Kardeş. "Vitamin, Vitamin". 33/1 Aralık (1946):16.

Dr. Agâh Neş่et. "Çocuk Giysisi Nasıl Olmalıdır”. Gürbüz Türk Çocuğu, 38/Teşrin-i Sani (1929): 12.

Dr. Ali Rıfat. "Çocuk Memleketin Varlığı, Ümidi, İstikbali Her şeydir”. Gürbüz Türk Çocuğu. 81/Temmuz (1933): 13-18.

Dr. Ali Rıfat. "Çocuk Sıhhati ve Bunun Ehemmiyeti”. Gürbüz Türk Çocuğu, 81/ Temmuz (1933): 13-18.

Dr. Ali Şükrü Bey. "Banyonun Faideleri ve Sihhi Banyo Usulleri”. Türk Çocuğu, 7/ Nisan (1927):15-18.

Dr. Ali Şükrü Bey. "Çocuk Bakımı İlmi: Dr. Ali Şükrü Bey’in Mütalaası”. Çocuk Haftasi c.2, /23 Nisan (1930): 75, 76.

Dr. Ali Şükrü Bey. "Çocuk Çamaşırları Nasıl Olmalıdır?”. Türk Çocuğu, 6/Mart (1927): 8-12.

Dr. Ali Şükrü Bey. "Sağlam Çocukların Muhtelif Aylarında Bulunması Lazım Olan Evsaf". Gürbüz Türk Çocuğu. 8/1 Mayıs (1927): 5-10.

Dr. Ali Şükrü Bey. "Yeni Doğmuş Çocukların Bazı Hususiyetleri”. Gürbüz Türk Çocuğu. 9/1 Haziran (1927): 1-7.

Dr. Ali Şükrü. "Çocuk Çamaşırları" Çocuk Haftası. c.2/23 Nisan (1930): 91-94.

Dr. Ali Vahit. “Bebek Ne İle Beslenir II?”. Gürbüz Türk Çocuğu. 56/Mayıs (1931): 21-23.

Dr. Asım İyen. "Hekim Öğütleri: Çocuk Bakımı". Gürbüz Türk Çocuğu. 95/İkinci teşrin (1934.): 16.

Dr. Fahrettin Kerim. "Çocuk Banyosu”. Sihhi Sahifeler. 8/15 Ağustos (1923): 125.

Dr. Fahriye. "Ana Sütü”. Gürbüz Türk Çocuğu. 97/Birinci kanun (1934): 9-12.

Dr. Fahriye. "Bol Beslenme (1)". Gürbüz Türk Çocuğu. 108/Birinci kanun (1935): 1115.

Dr. Fahriye. "Bol Beslenme (2)". Çocuk. 1/İkinci kanun (1936): 14, 15.

Dr. Fahriye. "Bol Beslenme (3)". Çocuk. 2/Şubat (1936): 14, 15.

Dr. Fahriye. "Çocuğun Ruhi Oluşu” Gürbüz Türk Çocuğu”. 103/Temmuz (1935): 1417.

Dr. Fahriye. "Çocuk Beslenmesi Bakımı" Gürbüz Türk Çocuğu”. 99/Şubat (1935): 9-13.

Dr. Fahriye. "Sütnine ile Besleme”. Gürbüz Türk Çocuğu. 98/İkinci kanun (1935): 9-11.

Dr. Fatma Arif. “Çocuk Hıfzıssıhhası”. Çocuk Haftası. 23 Nisan 1934, (23 Nisan Özel sayıs1): 75-83.

Dr. Feridun Neşet Bey. "Sıhhi Metinler: Vücudumuz". Yeni Yol. 29/22 Mart (1924): 67,68 . 
Dr. Fuad Umay. “Çocuklarımızın Yüzde Yetmişi Ölüyor”. Türk Çocuğu. 5/Mayıs (1927): 1-3.

Dr. G. Barrund. “Çocuklarda Güneş Banyosu ve Kürlerin Tekniği”. Gürbüz Türk Çocuğu. 66/Mart 1932): 12, 13.

Dr. İhsan Hilmi Bey. “Doktor İhsan Hilmi Bey Diyor ki: Çocuk Bakımında En İyi En Muvafık Usul”. Çocuk Haftası. c.2/23 Nisan (1930): 72, 24.

Dr. Kilisli Rifat. “Doğuştan Sonraki Gelişme”. Gürbüz Türk Çocuğu. 99/Şubat (1935): 24-32.

Dr. M.Ç. “Çocuk Nasıl Büyütülür”. Sthhi Sahifeler. 5/15 Mayıs (1924): 80.

Dr. Niyazi Ali Bey. “Çocuk Nasihat Yuvaları: Doktor Niyazi Ali Bey’in Fikri”. Çocuk Haftas1. c.2/23 Nisan (1930): 77, 78.

Dr. Reşit Galip. “Çocukları Koruyunuz”. Çocuk Haftası. c. 2/23 Nisan (1930): 9, 10.

Dr. Rıza Tahir Bey. "Çocuk Bakımına Ait Öğütler”. Türk Çocuğu. 14/Teşrin-i sani (1927): 18, 19.

Dr. Rıza Tahir Bey. "Doğumundan İtibaren Sütten Kesilinceye Kadar Çocuk Bakımı”. Türk Çocuğu. 14/Teşrin-i sani (1927): 18, 19.

Dr. Süreyya Hidayet. "Şişmanlık ve Bundan Korunmak Kurtulmak”. Sıhhat Almanakı, İstanbul: Kader Matbaas1, 1370/1951, 870.

Dr. Şadiye Muhiddin. “Diş Bakımı ve Sıhhatimiz”. Gürbüz Türk Çocuğu. 74/Birinci kanun (1932): 15-17.

Dr. Şadiye Muhiddin. “Dişleri Koruma Usulleri”. Gürbüz Türk Çocuğu. 87/Şubat (1934): 30, 32.

Dr. Şemsi Mutver. “En Büyük Milli Davamız”. Çocuk Doktoru. 7/Ekim (1946): 2-5.

Dr. W.Feer, çev., Dr. Cihat Gürson, “Çocuklarımızı Nasıl Beslemeliyiz”. Çocuk Doktoru, 4/Temmuz (1946): 2-3.

Dr. W.Feer. çev., Dr. Cihat Gürson, “Çocuğu Nasıl Beslemeliyiz”. Çocuk Doktoru. 3/ Haziran (1946): 2-4.

Ediz Hasan Ali “1001 Soru ve Cevap: İnsanlar Ne Zamandan Beridir Yıkanıyorlar?”. Şen Çocuk. 4/28 Kasım (1945): 9.

Ege Nezahat, Nurettin. "Sağlığımızı Koruyalım: Güneş Işı̆̆ının Tilsımı”. Doğan Kardeş. 180/9 Mart (1950): 2.

Ege, Nezahat Nurettin. "Sağlığımızı Koruyalım: Niçin Mevsime Göre Giyiniriz?". Doğan Kardeş, 186/20 Nisan (1950): 5.

Emin Şükrü. “Anne Sütünden Mahrum Olan Çocukları Besleme Sanatı”. Türk Çocuğu, 12/1 Eylül (1927): 6-9.

Emin Şükrü. “Çocuk Yetiştirmek Büyütmek İnce Bir Sanattır”. Türk Çocuğu. 11/ Ağustos (1927): 12-15.

Fatma Arif. “Çocuklarınıza Saf Hava Aldırınız Yalnız Sıhhi Tarzda Taşıyınız”. Gürbüz Türk Çocuğu. 40/Kanun-1 sani (1930): 12, 13.

Fatma Reşid. "İçtimai ve Sıhhi Dertlerimizden Biri: Doğduktan Sonra Ölen Çocuklar Değil Doğmadan Ölen Çocuklar Meselesi”. Türk Çocuğu. 167Kanun-1 sani 
(1928): 1-3.

Fatma Reşid. "Şişman Çocuk Sihhatlimidir?". Türk Çocuğu. 13/1 Teşrin-i evvel (1927): 13.

Feridun Neşet Bey. "Sıhhi Sütunlar: Mukaddime”. Yeni Yol. 28/15 Mart (1924): 2.

Foucault, Michel. Cinselliğin Tarihi, 1, çev., Hülya Tufan, 2. bs. İstanbul: Afa Yayınları, 1993.

Foucault, Michel. Toplumu Savunmak Gerekir. 6. bs. çev., Şahsuvar Aktaş İstanbul: Yapı Kredi Yayınları, 2013.

G. Ç., "Sağlığımızı Koruyalım”. Cumhuriyet Çocuğu. 21/Nisan (1938): 376.

Gürbüz Türk Çocuğu, “Çocuklara Ne Yedirmeli?”. (İngilizceden çeviren M.F). 52/ İkinci kanun (1931): 6-7.

Gürbüz Türk Çocuğu. "Vitamin: Çocuğun Gidasından Vitamini Azaltmak Onu Ölüme Mahkûm Etmektir”. 56/Mayıs (1931): 9,10.

Gürbüz Türk Çocuğu. “Annelere Çocuk Bakımı”. 58/Temmuz (1931): 8.

Gürbüz Türk Çocuğu. "Baş Başa: Doğum ve Çocuk Himayesi”. 49/Teşrin-i evvel (1930): 3 .

Gürbüz Türk Çocuğu. "Çocuğun Zekâsı Gıdasına Bağlıdır”. 34/Temmuz (1929): 9-11. Gürbüz Türk Çocuğu. "Çocuk Bakımına Ait Öğütler: Annelere”. 20/Mayıs (1928): 6.

Gürbüz Türk Çocuğu. “Çocuklara Güneş Banyosu Yaptırınız”. 34/Temmuz (1929): 5, 6.

Gürbüz Türk Çocuğu. “Diş Fırçası Ailesinin Hikâyesi”. 20/Mayıs (1928): 16, 17.

Gürbüz Türk Çocuğu. "Keçi Sütü”. 34/Temmuz (1929): 12.

Gürbüz Türk Çocuğu. "Vaktinden Önce Doğan Çocuklar”. 66/Mart (1932): 7, 8.

Gürbüz Türk Çocuğu. "Yazın Ne Giydirmeli?” 35/Ağustos (1929): 17.

Hikmet Şevki. “Amcamın Köşesi, Çocuğun Gıdası”. Gürbüz Türk Çocuğu. 19/Nisan (1928): 6-7.

Hikmet Şevki. “Çocuğun Telebbüs Tarzı” Gürbüz Türk Çocuğu”. 30/Mart (1929): 10, 11.

Lokman Hekim. "Çocukların Gıda Meselesi: Bir Fransız Doktor Neler Söylüyor". Çocuk Duygusu, 33/12 Mayıs (1938): 1.

Lokman Hekim. “Güneşte Derisini Yakanlara Üzülüyorum”. Çocuk Duygusu. 48/26 Ağustos (1938): 1.

Lokman Hekim. "Hekim Ögütleri: Hava Banyosu”. Çocuk Duygusu. 27/20 Eylül (1937): 13.

Lokman Hekim. "Hekim Öğütleri: Temiz Hava En Önemli Gıdadır”. Çocuk Duygusu. 38/26 Haziran (1938): 7.

Lokman Hekim. "Hekim Öğütleri: Uykunuza Dikkat Ediniz”. Çocuk Duygusu. 20/7 Nisan (1938): 12.

Lokman Hekim. "Hekim Öğütleri: Vaktinde ve Tam Uyumak”. Çocuk Duygusu, 39/23 Haziran (1938): 7. 
M. Nihat. “Çocuk Nasıl Giydirilmeli: Bir Doktorun Nasihatleri”. Gürbüz Türk Çocuğu. 34/Temmuz, (1929): 16, 17.

Mazhar Osman. "Hergünkü Yemeklerimizin Beslenme Derecesi, İnsana Ne Kadar Yemek Lazım - İnsan Nasıl Zayıflamalı - Nasıl Şişmanlamalı”. Sıhhat Almanakı, İstanbul: Kader Matbaas1, 1370/1951, 88-92.

Mehmed Nuri. “Çocukların Gıdası” Hayat ve Sihhat. 1 Nisan (1921): 17-21.

Mevhibe Ziya. “Açık, Temiz Havanın Kudreti”. Gürbüz Türk Çocuğu. 24/Eylül 1928): $4,5$.

Mithat Ömer. “Sütanaya, Dadıya, Mürebbiye, Hizmetçiye Dair”. Gürbüz Türk Çocuğu. 31/Nisan (1929): 3, 4.

Okay, Cüneyd. Eski Harfli Çocuk Dergileri, İstanbul: Kitabevi, 1999.

Özmen (İstanbul saylavı). “Çocuk”. Gürbüz Türk Çocuğu. 102/Haziran (1935): 9-11.

Prof. Dr. İhsan Hilmi. "Yeni Doğmuş Çocuk Karşısında Babanın Vazifesi”. Gürbüz Türk Çocuğu. 81/Temmuz (1933): 19-21

Prof. Dr. Sait Cemil Bey. “Besi İşinde Son Hakikatler”. Gürbüz Türk Çocuğu. 38/ Teşrin-i sani (1929): 16, 17.

Resimli Dünya. “Nasıl Zayıflamalı, Nasıl Şişmanlamalı?”. 1/Kanun-1 evvel, (1924): 15.

Resimli Mecmua. "Vücut Makinesi Nasıl İşler Kalır?". 50/19 Mayıs (1927): 14.

Reşit Galip. "Köy Muallimleri ile Sağlık Konuşmaları”. Muallim Kitapları. No, 1, İstanbul: Devlet Matbaası, 1933.

Rıza Tahir Bey. "Yeni Doğan Çocukların Temizliğine Dikkat Etmek Ana ve Babaların En Büyük Vazifesidir”. Gürbüz Türk Çocuğu. 29/Şubat (1929): 12, 13.

Selim Sırrı. "Genç Annelerle Hasbıhal: Yeni Doğan Yavrular İçin Umumi Tavsiyeler”. Gürbüz Türk Çocuğu. 28/Kanun-1 sani (1929): 6.

Sevig,Vasfi Raşit. “Temizlik” Çocuk. 260/22 İkinci teşrin (1941):1.

Sezai Bertan. “Temizlik ve İntizam”. Çocuk Güneşi. 6/28 Ekim (1950): 10.

Süreyya Asım. “Açık Havada Büyüyen Çocuk”. Gürbüz Türk Çocuğu. 30/Mart (1929): 16.

Süreyya Asım. "Kapalı Odalarda Yetişen Yavru”. Gürbüz Türk Çocuğu. 31/Nisan (1929): 9.

Ş.Orhan. “Temizlik ve İntizam”. Çocuk. 131/24.3(1939): 12, 13.

Şen Çocuk. "1001 Soru ve Cevap: Sabun Niçin Temizler, Niçin Yıkar”. 5/5 Aralık (1945): 2.

Taluy, Nihal Yalaza. "Hayat Bilgisi, Aile Bilgisi: Odamızın Temizliğì". Çocuk, 5/9 Mart (1945): 3.

Taluy, Nihal Yalaza. "Hayat Bilgisi, Aile Bilgisi: Odanızı Nasıl Havalandırırsınız?”. Çocuk. 7/2 Nisan (1945): 3.

Tarhan Taraç. “Gürbüz Çocuk Nasıl Meydana Gelir”. Türk Çocuğu, 2/Teşrin-i sani (1926): 8, 9.

Temel, Mehmet. Atatürk Döneminde Bulaşıcı ve Salgın Hastalıklarla Mücadele. Ankara: Nehir Yayınları, 2008. 
Tok Sözlü. “Vücut Makinesini İyi Kullanmalı”. Resimli Mecmua. 42/13 kanun-1 sani (1926): 2.

Türk Çocuğu. “Annelik Sanatı: Bu Kutsi Sanatı Tamim Etme Sanatıdır”. 14/Teşrin-i sani (1927): 21

Türk Çocuğu. “Annelerle Çocuklara Sıhhi Öğütler”. 4/Kanun-1 sani (1927): 33, 34.

Türk Çocuğu. "Annelik Sanatı: Bu Kutsi Sanatı Tamim Etme Sanatıdır”. 14/Teşrin-i sani (1927): 21.

Türk Çocuğu. "Bilmeyerek Yapılan Hayat Hırsızlıkları: Çocuklarımız Yalnız Bizim Değil Vatanındır da”. 3/Kanun-1 evvel (1926): 2.

Türk Çocuğu. "Bu Kaideleri Ezberleyinceye Kadar Okuyunuz”. 23/Ağustos, (1928): 21.

Türk Çocuğu. "Çocuğunuza Rehber Olunuz". 4/Kanunun-1 sani (1927): 1.

Türk Çocuğu. “Çocuk Bakımına Ait Öğütler: Çocuk Beslemek”. 17/Şubat (1928): 5, 6.

Türk Çocuğu. "Çocuk Bakımına Ait Öğ̈ütler”. 16/Kanun-1 sani (1928): 14, 15.

Türk Çocuğu. "Çocuklara Hangi Gıda İntihab Olunmalıdır?”. s. 11 (Temmuz 1927):25-27.

Türk Çocuğu. "Ebeveynin Günahları”. 4/Kanunun-1 sani (1927): 13-15.

Türk Çocuğu. “Ebeveynin Vazifeleri ve Ebeveynlik”. 2/Teşrin-i sani (1926): 1.

Türk Çocuğu. “Temiz Aile Manzumeleri”. 1/Teşrin-i evvel (1926): 4.

Türk Çocŭ̆u. "Uyanıklar Mektebi Çocuklarının Sıhhat Cetveli”.4/Kanunun-ı sani (1927): 5-10.

Türk Çocuğu. "Uyanıklar Mektebi Çocuklarının Sıhhat Cetveli".4/Kanun-1 sani (1927): 6-7.

Yeni Yol. “Güneş Nasıl çarpar”. 68/19 Mart (1925): 709.

Yeni Yol. "Hekim Aksungur Bey’in Öğütleri: Temizlik”. 66/5 Mart (1925): 689, 699.

Yeni Yol. “Şişmanlamak İçin Yeni Bir Usul”. 45/9 Teşrin-i evvel, (1924): 236, 239.

Yeni Yol. "Su ve Tarak Kullanmayan Millet”. 66/5 Mart (1925): 686, 687.

Zeki Mesut. "Çocuk Hakkında Günlük Arkadaşlarımız Ne Yazıyor: Çocuk Sıhhati”.

Gürbüz Türk Çocuğu, 40/Kanun-i sani (1930): 24. 


\title{
The Art of Motherhood: Children's Bodily Construction in Children's Periodicals Duruing the Early Republic
}

\author{
SEVCAN BAŞBOĞA
}

\begin{abstract}
In the course of the rise of modern states throughout the 19th and 20th centuries, the domain of the human factor and as well as the body, health, and industrious capacity of its productive generations have acquired an ever increasing significance, as to the defence and protection of the boundaries of the nation-state and its economic development. Within their bio-political perspective and responsibility to regulate the population in relation to its prospective social, political, and economic welfares and securities, modern structures of authority were implementing the "regulation" of this particular domain through a mechanism of power. Within the framework of these regulatory mechanisms of surveillance counted particularly themes such as the population's birth, death, life-span, fertility rate, general health status, epidemics, frequency of illness, hygiene, and nutrition.

In this context, corresponding to the ever waxing structure of the modern state, the population as well as processes pivotal to the population have constituted a major sphere of intervention during the period of the Turkish Republic. Major losses of the population, which could have been actively employed in processes of production and defence, as result of long lasting wars prior to the foundation of the Republic, added by the remainder's struggle with unattended and epidemic illnesses, proved just how important the matter of the population was for the future of the country.

This paper mainly seeks to answer how efforts pertaining to the population, attempts to increase the population and to improve the health of society starting from its children have been reflected in children's periodicals during the period of the Early Republic. It aims to elaborate the designated insufficiencies in child care, and the corresponding suggestions and messages directed at mothers and parents in this period by the mediation of children's periodicals, as well as the habits children, as future citizens of the Republic, were expected to acquire in their daily life. It will moreover be explored what type of body, idealized within the population perspective of the early Republic, emerges in the light of these descriptions, and why such a type of body had been called for.

The focus of this study are the particular reasons, justifications, the methods and recommendations that have accompanied the re-regulation of society by the mediation of children's periodicals during the period of the early Republic. In this context, child death was counted among the primary obstacles to population growth, and the means to surpass this problem were the methods and recommendations to mothers and parents of how to raise healthy and fit children illustrated in children's periodicals. As such, the paper reveals how a new conception of the individual and society that puts the notion of a healthy body and healthy habits at its very centre has been attempted to be constituted by means of children's periodicals.
\end{abstract}

Keywords: Modern state, Children's periodicals, Child care, Idealized body. 